\title{
Potential Job Creation in Nevada as a Result of Adopting New Residential Building Energy Codes
}

Final Report

MJ Scott

JM Niemeyer

September 2013

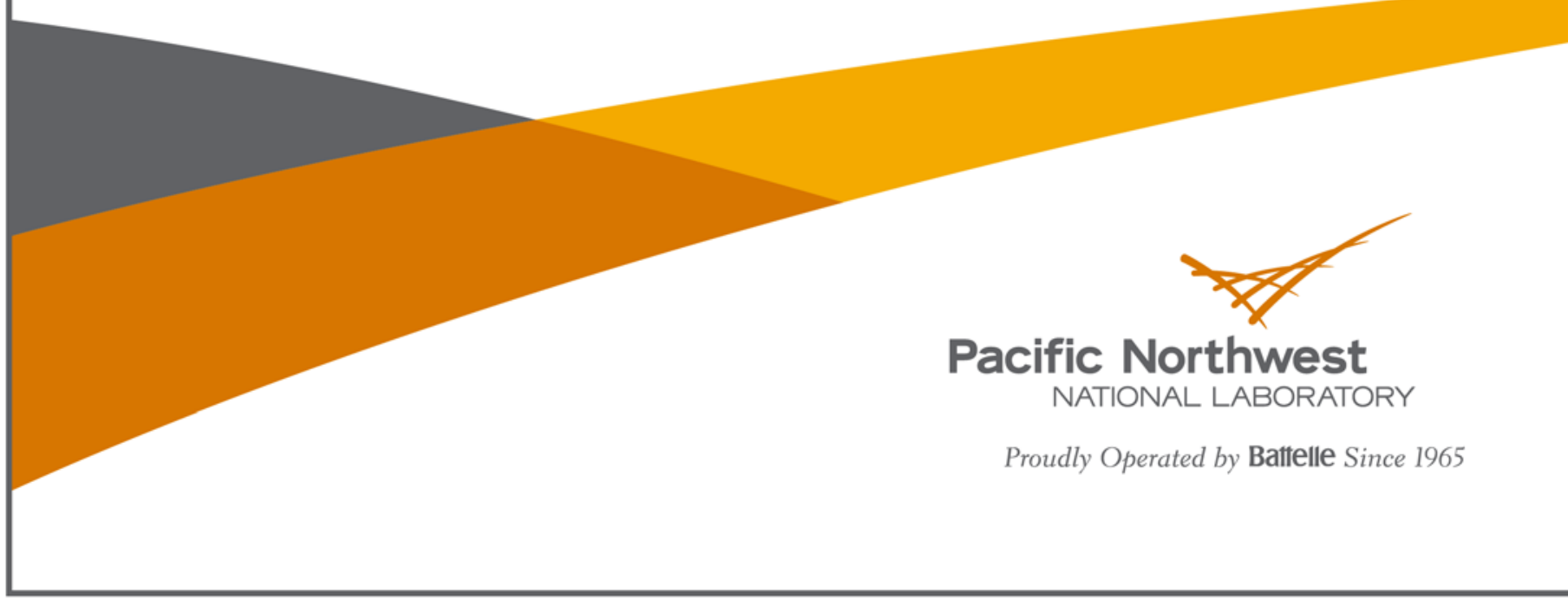




\title{
DISCLAIMER
}

This report was prepared as an account of work sponsored by an agency of the United States Government. Neither the United States Government nor any agency thereof, nor Battelle Memorial Institute, nor any of their employees, makes any warranty, express or implied, or assumes any legal liability or responsibility for the accuracy, completeness, or usefulness of any information, apparatus, product, or process disclosed, or represents that its use would not infringe privately owned rights. Reference herein to any specific commercial product, process, or service by trade name, trademark, manufacturer, or otherwise does not necessarily constitute or imply its endorsement, recommendation, or favoring by the United States Government or any agency thereof, or Battelle Memorial Institute. The views and opinions of authors expressed herein do not necessarily state or reflect those of the United States Government or any agency thereof.

\author{
PACIFIC NORTHWEST NATIONAL LABORATORY \\ operated by \\ BATTELLE \\ for the \\ UNITED STATES DEPARTMENT OF ENERGY \\ under Contract DE-AC05-76RL01830
}

Printed in the United States of America
Available to DOE and DOE contractors from the Office of Scientific and Technical Information,
P.O. Box 62, Oak Ridge, TN 37831-0062;
ph: (865) 576-8401
fax: $(865) 576-5728$
email: reports@adonis.osti.gov
Available to the public from the National Technical Information Service 5301 Shawnee Rd., Alexandria, VA 22312
ph: (800) 553-NTIS (6847)
email: orders@ntis.gov <http://www.ntis.gov/about/form.aspx>
Online ordering: http://www.ntis.gov

This document was printed on recycled paper.

(8/2010) 


\section{Potential Job Creation in Nevada as a Result of Adopting New Residential Building Energy Codes}

Final Report

MJ Scott

JM Niemeyer

September 2013

Prepared for

the U.S. Department of Energy

under Contract DE-AC05-76RL01830

Pacific Northwest National Laboratory

Richland, Washington 99352 



\section{Contents}

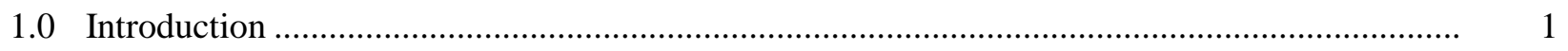

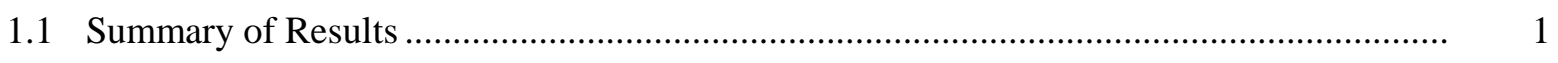

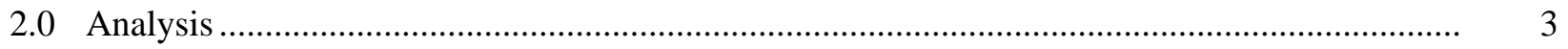

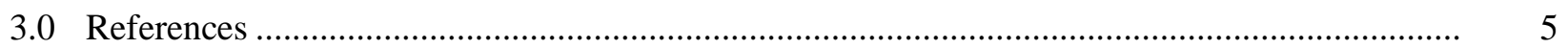

Appendix A-A Method to Estimate Job Creation Potential in States as a Result of Enhanced

Building Energy Code Adoption .................................................................................... A.1

Appendix B-Long-Term Statewide Savings and Cost Data ..................................................... B.1

\section{Figures}

A.1 Changes in Payment Flows Associated with More Energy-Efficient Residential Building Energy Codes

A.2 Climate Zones of the United States.

\section{Tables}

1 Investments and Other Cash Flows in the Nevada Economy Associated with Upgrading the Residential Building Energy Code: Inputs to the IMPLAN Model ..................................... 4

2 Potential Economic Impact in the Nevada Economy Associated with Upgrading the Residential Building Energy Code: Jobs and Labor Income

A.1 Incremental Investment from More Efficient Building Energy Codes by U.S. Climate Zone

A.2 Weighted Average Incremental Residential Investment Costs per Average Unit, 2010.

A.3 Number of Residential Units Authorized by Permits by State, 2010, and Average Number 2000-2010

A.4 Statewide Incremental Investment Costs to Meet 2009 IECC and 2012 IECC

Residential Building Energy Codes by State in 2010

A.5 Statewide Incremental Investment Costs to Meet 2009 IECC and 2012 IECC Residential Building Energy Codes by State at the Average Level of Housing Starts, 2000-2010

A.6 Mean Value of Annual Electricity Savings per Housing Unit by State by Building Energy Code Increase

A.7 Mean Value of Annual Natural Gas Savings per Housing Unit by State by Building Energy Code Increase

A.8 Mean Value of Annual Fuel Oil Savings per Housing Unit by State by Building Energy Code Increase 
A.9 Average Incremental Mortgage Payments per Housing Unit to Meet the 2009 and 2012

IECC Building Energy Codes

A.10 Average Incremental Property Tax Payments per Housing Unit to Meet the 2009 and 2012 IECC Building Energy Codes

A.11 Average Incremental Insurance Payments per Housing Unit to Meet the 2009 and 2012 IECC Building Energy Codes .....

A.12 Average Incremental Tax Deductions per Housing Unit to Meet the 2009 and 2012 IECC Building Energy Codes

B.1 Statewide Value of Annual Electricity Savings per Housing Unit by State by Building Energy Code Increase, 2010 Level of Housing Starts.

B.2 Statewide Value of Annual Natural Gas Savings by State by Building Energy Code Increase, 2010 Level of Housing Starts

B.3 Statewide Value of Annual Fuel Oil Savings by State by Building Energy Code Increase, 2010 Level of Housing Starts

B.4 Statewide Incremental Mortgage Payments to Meet the 2009 and 2012 IECC Building Energy Codes, Housing Starts Equal to 2010 Level

B.5 Statewide Incremental Property Tax Payments to Meet the 2009 and 2012 IECC Building Energy Codes, Housing Starts Equal to 2010 Level .

B.6 Statewide Incremental Insurance Payments to Meet the 2009 and 2012 IECC Building Energy Codes, Housing Starts Equal to 2010 Level

B.7 Other Statewide Consumer Spending Out of Energy Savings from Meeting the 2009 and 2012 IECC Building Energy Codes, Housing Starts Equal to 2010 Level

B.8 Statewide Value of Annual Electricity Savings per Housing Unit by State by Building Energy Code Upgrade, 2000-2010 Average Level of Housing Starts

B.9 Statewide Value of Annual Natural Gas Savings by State by Building Energy Code Upgrade, 2000-2010 Average Level of Housing Starts

B.10 Statewide Value of Annual Fuel Oil Savings by State by Building Energy Code Upgrade, 2000-2010 Average Level of Housing Starts

B.11 Statewide Incremental Mortgage Payments to Meet the 2009 and 2012 IECC Building Energy Codes, Housing Starts Equal to Average Level 2000-2010 ....

B.12 Statewide Incremental Property Tax Payments to Meet the 2009 and 2012 IECC Building Energy Codes, Housing Starts Equal to Average Level 2000-2010 .

B.13 Statewide Incremental Insurance Payments to Meet the 2009 and 2012 IECC Building Energy Codes, Housing Starts Equal to Average Level 2000-2010

B.14 Other Statewide Consumer Spending Out of Energy Savings from Meeting the 2009 and 2012 IECC Building Energy Codes, Housing Starts Equal to Average Level 20002010. 


\subsection{Introduction}

Are there advantages to states that adopt the most recent model building energy codes other than saving energy? For example, can the construction activity and energy savings associated with codecompliant housing units become significant sources of job creation for states if new building energy codes are adopted to cover residential construction? ${ }^{1,2}$ The U.S. Department of Energy (DOE) Building Energy Codes Program (BECP) asked Pacific Northwest National Laboratory (PNNL) to research and ascertain whether jobs would be created in individual states based on their adoption of model building energy codes.

Each state in the country is dealing with high levels of unemployment, so job creation has become a top priority. ${ }^{3}$ Many programs have been created to combat unemployment with various degrees of failure and success. At the same time, many states still have not yet adopted the most current versions of the International Energy Conservation Code (IECC) model building energy code, when doing so could be a very effective tool in creating jobs to assist states in recovering from this economic downturn.

\subsection{Summary of Results}

An analysis conducted by PNNL for BECP found that transforming the U.S. housing stock through the adoption of more energy-efficient building energy codes could create hundreds of jobs in each of several states, including Nevada. Between the years 2000 and 2010, Nevada built an average of nearly 30,200 new housing units per year. ${ }^{4}$ Even in the depressed building climate of 2010, the state still constructed over 6,400 new units. At the higher "typical” rate of construction, each year class of codecompliant construction in Nevada would support up to an additional 850 short-term jobs and up to an additional \$46 million in short-term labor income per year. In the long term, in addition to saving Nevada consumers \$11 million per year thereafter, each year class would annually provide support for up to 75 jobs and $\$ 2$ million in labor income in the state’s economy. ${ }^{5}$

The long-term impact is likely to be much greater than this, however. A constant rate of residential construction merely maintains the level of short-term impact because it depends on one-time additions to the stock of incrementally more efficient buildings. The segment of housing units affected by the upgraded ${ }^{6}$ building energy code continues to generate energy savings over the lifetime of the housing unit, in lieu of the housing unit that would have been built. Therefore, the annual level of energy savings (and resulting employment and income impacts) shifts upward as the housing stock built under the upgraded building energy code expands. For example, at a constant rate of construction for three years, the third year would see 850 short-term jobs supported, but the long-term component of support, which depends on the three years' worth of energy savings from code-compliant housing stock, would have grown to roughly $75+75+75=225$ jobs. This long-term impact would continue to accumulate in subsequent years until the entire housing stock eventually is transformed with code-compliant housing units. $^{7}$ In the long term, the long-term savings component dominates. Potential job creation for a single year class will fall into three categories:

Direct Job Creation This is job creation in the construction-related industries due to new workers designing, building, and inspecting new structures. In the short term, Nevada could see approximately 400 new jobs and \$27 million in labor income as a result of direct job creation. Energy savings would sustain about 35 direct jobs and 
\$0.4 million in finance, insurance, the retail and services sector, and government in the long term.

Indirect Job Creation Indirect job creation occurs in industries supplying inputs to the directly affected industries. This could affect manufacturers, suppliers, and retail stores. Nevada could see up to 205 indirect new jobs and \$9 million in labor income in the short term and support for about 30 jobs and \$1 million in labor income in the long term as a result of indirect economic activity.

Induced Job Creation This is job creation that occurs in the local economy as a result of increased consumer spending based on direct and indirect earnings. Induced employment occurs as workers in direct and indirect supporting industries spend money from their new jobs elsewhere in the local economy. Nevada could see up to 245 induced jobs and \$10 million in the short term, and support for about 10 jobs and $\$ 0.4$ million per year in the long term as a result of induced economic activity. 


\subsection{Analysis}

To calculate the impact of implementing an upgraded residential building energy code in Nevada, PNNL used IMPLAN ${ }^{\circledR}$, a widely accepted economic input-output model, to estimate employment impacts. ${ }^{8}$ IMPLAN, a product of MIG, Inc. (formerly Minnesota IMPLAN Group, Inc.), contains highly disaggregated data on regional economic indicators, and converts user inputs into employment impacts. It is based on social accounting between industries and within the distribution chain, and contains numerous economic multipliers to quantify direct, indirect, and induced employment impacts. Output from IMPLAN is in the form of direct, indirect, and induced economic output (gross state product), jobs, and labor income created or supported, as well as their associated multipliers.

As with most economic impact models, for IMPLAN to be able to estimate the impact of a given economic activity, it is necessary first to obtain estimates of the level of direct new spending that would occur in the economy as a result of that activity. Much of the research effort in an impact study is dedicated to collecting, analyzing, and organizing economic data to properly characterize the economic activity in question. In the current study, it was necessary to obtain or estimate data to characterize the comparative costs to build single-family and multifamily housing units in Nevada that are compliant with the 2012 IECC Residential Provisions. ${ }^{9}$ In addition, PNNL estimated the energy savings that result from the new code, the market value of those energy savings, and the likely distribution of the value of costs and savings across the various sectors of the Nevada economy. The methodological details are contained in Appendix A and the inputs to the model are shown in Appendix B. PNNL had already characterized most of the incremental investment, incremental savings, and consumer cash flows associated with construction and operation of more energy efficient residential buildings for national and state costeffectiveness studies of the 2009 and 2012 IECC residential provisions. The national study was published as DOE (2012a) and the Nevada state volume is available online (DOE 2012b). Those data were utilized in this study.

There are some methodological differences between the life-cycle cost and cash flow analyses in the residential building energy code cost-effectiveness studies on the one hand, and economic impact studies on the other. These differences result in slightly different treatment of the same data. Put simply, the cost- effectiveness studies emphasize the present value of discounted positive and negative cost streams from the perspective of a homeowner. ${ }^{10}$ Impact studies follow the consequences of changes in (for example) investments on the level of activity throughout the economy, regardless of whether or not the benefits of the investment exceed the costs. Thus, for example, energy savings that cost less than their value to produce are clearly beneficial to the homeowner, but an impact study is only concerned with the effect that both the savings and the costs have on the overall level of production, employment, and income in the economy, regardless of whether or not the investment is cost effective.

Table 1 summarizes the short-term and long-term cash flows in the Nevada economy associated with an upgrade of the residential building energy code from the current level to the 2012 IECC. This is the impact associated with one year's worth of new construction. It is divided into the short-term impacts associated with the construction period and the long-term annual impacts that occur during the lifetimes of the housing units that are built. The size of the impact depends on the level of future housing starts. Two levels of future housing starts are shown in Table 1- the depressed level that prevailed in 2010 and the more-typical average of the levels that prevailed from 2000 through 2010. These cash flows (positive or negative) are inputs to the IMPLAN model and are converted by the model into corresponding 
estimates of changes in potential short-term and long-term overall economic activity in the Nevada economy, as indicated in Table 2. The impact is shown at two levels of future housing starts-the depressed level in 2010 and the average level of housing starts from 2000 to $2010{ }^{11}$

Table 1. Investments and Other Cash Flows in the Nevada Economy Associated with Upgrading the Residential Building Energy Code: Inputs to the IMPLAN Model

\begin{tabular}{|c|c|c|}
\hline \multirow[b]{2}{*}{$\begin{array}{l}\text { Item and Direction of } \\
\text { Impact on Economy } \\
(+ \text { or }-)\end{array}$} & \multicolumn{2}{|c|}{ IECC 2009 to IECC 2012} \\
\hline & $\begin{array}{c}2010 \\
\text { Housing } \\
\text { Starts }\end{array}$ & $\begin{array}{l}\text { 2000-2010 Average } \\
\text { Housing Starts }\end{array}$ \\
\hline Housing Starts & 6,372 & 30,223 \\
\hline \multicolumn{3}{|c|}{ Short Term (Thousand 2011\$): } \\
\hline Construction (+) & 15,465 & 73,354 \\
\hline Finance Fees $(+)$ & 104 & 491 \\
\hline \multicolumn{3}{|c|}{ Annual Long Term (Thousand 2011\$): } \\
\hline $\begin{array}{l}\text { Mortgage Repayments } \\
(+)\end{array}$ & 892 & 4,231 \\
\hline Insurance (+) & 70 & 332 \\
\hline Property Taxes (+) & 140 & 665 \\
\hline Other Consumption (+) & 1,364 & 6,468 \\
\hline Electricity Sales (-) & 1,281 & 6,075 \\
\hline Natural Gas Sales (-) & 1,013 & 4,805 \\
\hline Fuel Oil Sales (-) & 6 & 30 \\
\hline
\end{tabular}

Table 2. Potential Economic Impact in the Nevada Economy Associated with Upgrading the Residential Building Energy Code: Jobs and Labor Income

\begin{tabular}{lcc}
\hline & \multicolumn{2}{c}{ IECC 2009 to IECC 2012 } \\
\cline { 2 - 3 } \multicolumn{1}{c}{ Impact } & $\begin{array}{c}\text { 2010 Housing } \\
\text { Starts }\end{array}$ & $\begin{array}{c}\text { 2000-2010 Average } \\
\text { Housing Starts }\end{array}$ \\
\hline Housing Starts & 6,372 \\
\hline \multicolumn{3}{c}{ Short-Term Impacts } \\
\hline Jobs & 180 & 30,223 \\
\hline $\begin{array}{l}\text { Labor Income } \\
\text { (Million 2011\$) }\end{array}$ & 10 & 850 \\
& Annual Long-Term Impacts \\
\hline Jobs & 15 & 46 \\
\hline $\begin{array}{l}\text { Labor Income } \\
\text { (Million 2011\$) }\end{array}$ & $<0.5$ & 75 \\
\hline
\end{tabular}




\subsection{References}

DOE - U.S. Department of Energy. 2012a. National Energy and Cost Savings for New Single-and Multifamily Homes: A Comparison of the 2006, 2009, and 2012 Editions of the IECC. Building Energy Codes Program, Washington, D.C. Accessed June 9, 2012 at: http://www.energycodes.gov/sites/default/files/documents/NationalResidentialCostEffectiveness.pdf.

DOE - U.S. Department of Energy. 2012b. Nevada Energy and Cost Savings for New Single- and Multifamily Homes: 2012 IECC as Compared to the 2009 IECC. Building Energy Codes Program, Washington, D.C. Accessed April 30, 2013 at: http://www.energycodes.gov/sites/default/files/documents/NevadaResidentialCostEffectiveness.pdf

\footnotetext{
${ }^{1}$ Throughout this document we collectively refer to model building energy codes and building energy codes. The former are promulgated by the International Code Council (ICC) as models for adoption in legislation or regulation. The latter term will be used when referring to their adopted by reference or by incorporating the text of the model code directly in laws or regulations, with or without amendments.

${ }^{2}$ The analysis in this report assumes that a newly constructed housing unit minimally complies with the building energy code in effect the year it is constructed.

${ }^{3}$ The analysis in this report covers the 50 states and the District of Columbia, but not U.S. territories.

${ }^{4}$ Housing units refers to residential buildings as defined in the IECC model building energy code: one- and twofamily buildings, townhouses and each individual dwelling unit in multifamily buildings not over three stories in height. Housing stock is the existing number of such units at a point in time. Manufactured housing, which is regulated by 24 CFR Part 3280, is not considered in this study.

${ }^{5}$ The analysis in this report assumes that a newly constructed housing unit minimally (just) complies with the building energy code in effect during the year it is constructed and supports construction jobs only during the year of construction (short term). The total number of housing units constructed during a given year comprise a "year class" (e.g., the class of 2012 is all units built during 2012), each unit of which is assumed to minimally comply with the building energy code being analyzed (e.g., the 2012 IECC as applicable to residential buildings) during its lifetime (long term). The long-term savings shown in the report are shown only for a single year class and are calculated by subtracting estimated energy use complying with a more energy-efficient building energy code (e.g., 2012 IECC) from energy use complying with the baseline code (e.g., 2009 IECC or other existing code currently in effect). The analysis ignores further potential building energy code changes, any future energy efficiency improvements to a given year class, any efficiency improvements resulting from home energy rating systems (HERS) or other "marketpull” or incentive programs, and any efforts to go "beyond code." These are all considered separate energy efficiency improvement efforts, not impacts from applying the more energy-efficient building energy code. The analysis implicitly assumes that energy savings come only from application of a given upgraded code to all subsequent new construction.

${ }^{6}$ Throughout this report, the term "upgrade" means to adopt some variant of a building energy code more energy efficient than the current one or a new edition of a model energy code that is more energy efficient than the previous edition.

${ }^{7}$ The impact shown is conservative because we have assumed that once the 2012 IECC model building energy code is adopted, that version of the code remains in place forever. However, the ICC regularly upgrades its model code, and jurisdictions regularly upgrade their building energy codes in response, so in reality further impacts can be expected as a result of these upgrades.

${ }^{8}$ IMPLAN. Version 3.0. Hudson, WI: MIG, Inc.

${ }^{9}$ The definition of residential buildings does not change between the 2009 and 2012 IECC; however, the latter edition has totally separate provisions for residential buildings (IECC Residential Provisions), while the former did not totally separate residential and commercial building provisions.

${ }^{10}$ Homeowner as used here includes renters and lessees. Renters and lessees are assumed to indirectly pay the building owner's mortgage and property taxes through rent or lease payments and directly or indirectly (as part of the rent or other fee) also pay the energy bill.

${ }^{11}$ Housing start data were obtained from the U.S. Department of Housing and Urban Development (HUD) State of the Cities Data Systems (SOCDS), which reports total new single family and multifamily housing units authorized
} 
by building permits each year in every state and the District of Columbia. Units authorized include 1, 2, 3-4, and 5+ unit buildings. Some new $5+$ unit buildings likely were over three stories in height and therefore would have been covered by the provisions of the IECC building energy code applicable to commercial buildings rather than the residential provisions. However, in this analysis all units were assumed to be covered by the residential provisions. In Nevada in 2010 about 17 percent of all units were in the multifamily category. Separately, the U.S. Census Bureau data shows that the percentage of units in multifamily residential buildings of four or more stories (considered commercial buildings in the IECC) varies considerably from year to year, but that the average from 2000-2010 was about 32 percent. This implies that, at most, about 5 percent of residential units might be covered by the commercial provisions of the IECC rather than residential provisions of the IECC and our estimates may be high by that amount. On the other hand, the building energy codes also apply to a portion of the several thousand residential additions, renovations, and alterations that occur in each year in Nevada. Restricting the analysis in this report only to new construction offsets at least some of the overstatement of impact resulting from the inclusion of high-rise multifamily. The SOCDS data are collected by the U.S. Census Bureau. SOCDS documentation notes that authorized units data on the Census website does not include concurrent year revisions to preliminary monthly data, nor does it reflect any of the revisions found in the final monthly data. Census displays only their originally published data while SOCDS data reflects all subsequent Census revisions. 
Appendix A

A Method to Estimate Job Creation Potential in States as a Result of Enhanced Building Energy Code Adoption 



\section{Appendix A}

\section{A Method to Estimate Job Creation Potential in States as a Result of Enhanced Building Energy Code Adoption}

\section{A.1 Introduction: How the Economy Works to Create Jobs}

The purposes of building energy codes are to save energy, save consumers money, reduce the negative environmental impacts of energy production and consumption, and reduce dependence of the economy on insecure sources of energy. Implementing new cost-effective building energy codes saves more dollars' worth of energy than it costs the economy, increasing national wealth and providing opportunities for economic growth. Additionally, like any other cost-effective investment, building energy codes can help create jobs and reduce unemployment.

Demand for a good or service generates demand for the resources needed to create the good or service and make it available for purchase. The values of the required resources are costs of production. Economists often categorize the required resources as labor, purchased materials and services, and purchased land and equipment costs. Because labor is a cost of production, the number of jobs and size of income growth in the economy is primarily associated with the scale of overall economic activity in the economy. However, because some sectors of the economy require more labor per dollar of output than others, the level of employment and income also depends on the distribution of economic activity among sectors. For example, most consumer spending and construction are "labor intensive" (require more labor per dollar of output) while most industrial production and the utility sectors are more "capital intensive" (require less labor per dollar of output). Thus, purchases from sectors with high labor requirements tend to generate more jobs per dollar of output. Because purchased materials, equipment, and services themselves must be produced, increased demand for final purchases-for example, a single-family housenot only creates demand for labor to build the house ${ }^{1}$, but also intermediate or indirect demand for labor and other resources to make the components such as windows, lumber, fiberglass, pipe, and supporting services such as architectural plans, legal documents, etc. Payments flow from the prospective homeowner or developer to the first level of suppliers of goods and services (final demand ${ }^{2}$ ) on to the indirect and intermediate suppliers, and finally to the economy as a whole. If the economy in question is the economy of, for example, a U.S. state, many of the payments go beyond the borders of the state to other states and ultimately, some to other countries. As payments increase or decrease in various sectors, the demand for labor and the number of jobs increases or decreases. The overall impact on jobs is the net effect of all of the increases and decreases in demand.

\section{A.2 How Building Energy Codes Create Jobs}

Pacific Northwest National Laboratory (PNNL) conducted research on the potential employment impacts associated with the adoption of and compliance with more energy-efficient residential building energy codes on a state-by-state basis. PNNL analyzed two sources of potential job creation: short-term impacts of the investment required to implement the codes, and the long-term impacts of the resulting energy savings. Figure A.1 is a simplified picture of payment flows within a state economy associated with a cost-effective upgrade to a residential building energy code. 
The figure is divided into the short term (1a), when an incremental investment is made with funds from the homeowner or developer and borrowed funds to comply with a more energy-efficient building energy code, and the longer term (1b), when the homeowner or renter enjoys lower energy bills, but must pay back the mortgage, purchase insurance, and pay increased property taxes. ${ }^{3}$

\section{1a. Short Term}

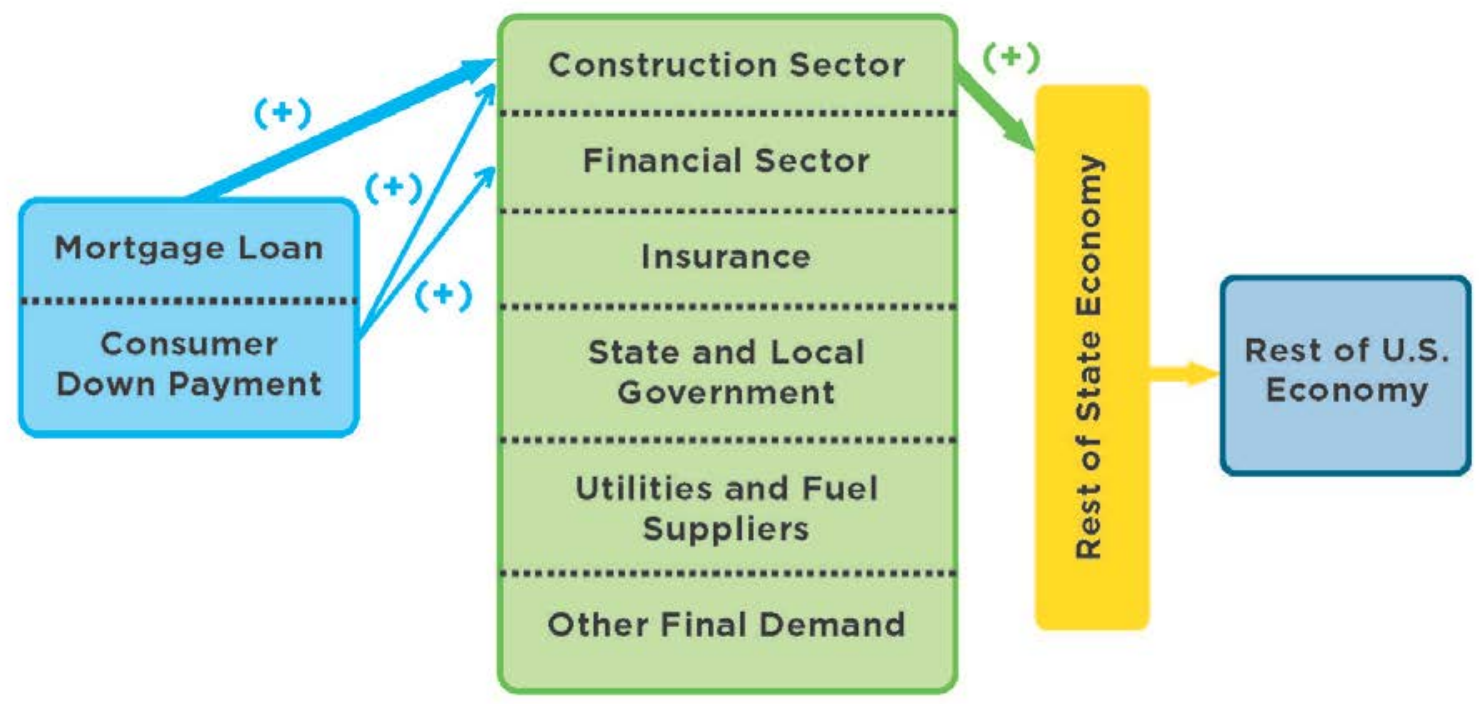

\section{1b. Long Term}

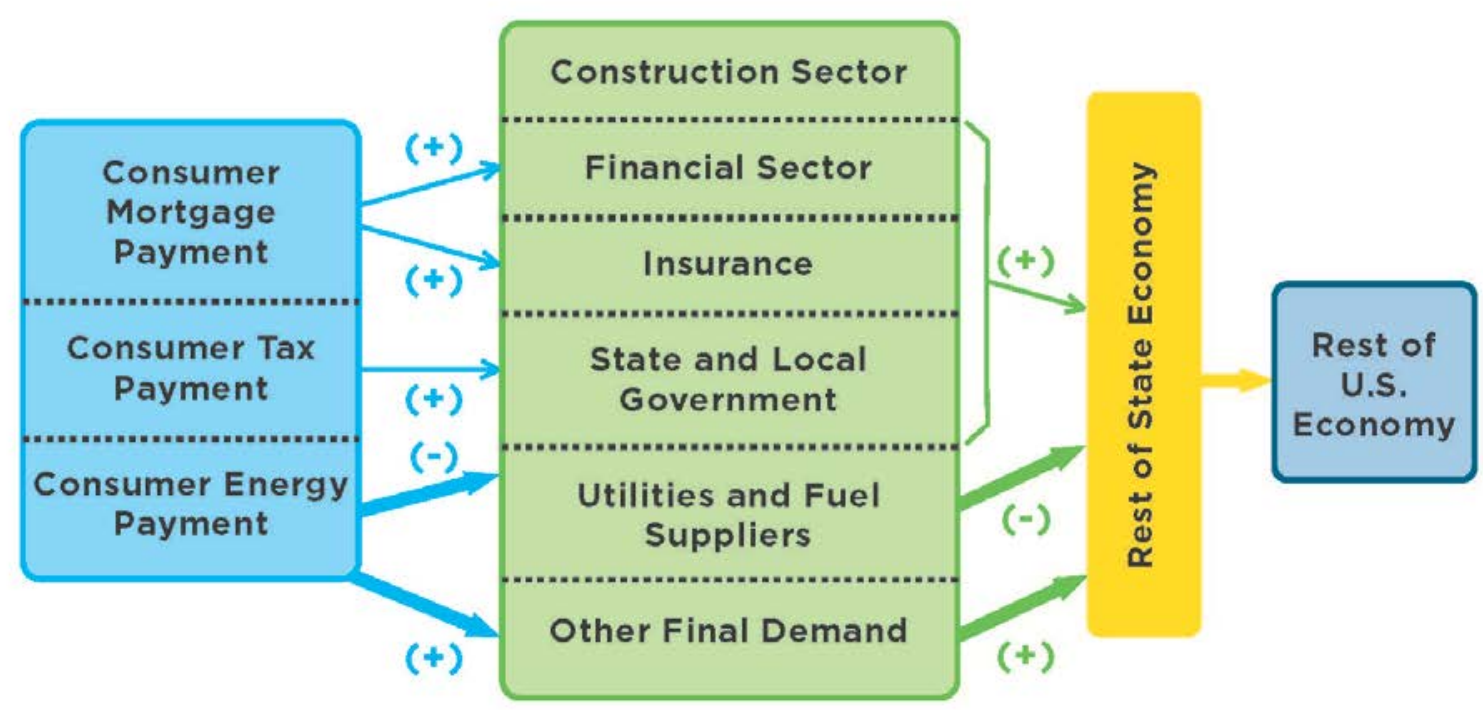

Figure A.1. Changes in Payment Flows Associated with More Energy-Efficient Residential Building Energy Codes 
Potential job growth comes from the following sources. In the short term, as shown in Figure A.1, implementing upgraded building energy codes requires an incremental investment in the housing stock, paid for with a direct increase in the size of the mortgage on the building and an increase in the size of the consumer or developer down payment on the loan for the new housing unit. These are shown in 1a as increases in payment flows (“+”) primarily into construction, but also include some fees to financial institutions to arrange the mortgage. The investment itself requires short-term increases in economic activity within the construction industry. This economic activity directly generates labor hours and income in construction, and provides markets for goods and services in industries in the rest of the economy that supply windows, insulation, lighting and other items required by the building energy codes. Additional labor hours in manufacturing and distribution channels are required to fill these orders. The prospective homeowner (or developer) is assumed to have saved most or all of the down payment, and will not reduce other purchases as a result of having to make the down payment. The main payment impacts are shown in the heavier arrows.

In the long term (1b), more energy-efficient buildings save energy over several decades. The energy savings that occur due to a more energy-efficient housing stock are real resource cost savings to the economy, not just the homeowner, developer, or renter. Because building energy codes are cost-effective (i.e., they save more over time than they initially cost to satisfy) (DOE 2012), they create a real and permanent increase in wealth. The payment flows associated with long-term consumer savings are shown in Figure A.1 part 1b. As in 1a, the predominant payment flows are shown as heavier arrows. First, the homeowner or developer/renter (directly/indirectly) experiences a reduction in payments to electric and gas utilities and fuel suppliers (shown as “-” payment to utilities and fuel suppliers). Out of those savings, the homeowner or building owner begins to pay back the increment to the mortgage loan and insurance required should the building be more expensive to construct under an upgraded building energy code, and pays the higher property tax bill associated with the more valuable building ("+" flows to state and local government and the financial sector). The rest of the money associated with the energy savings can be spent on other goods and services in the economy just like any other income, in turn creating additional employment opportunities. While the energy generation and distribution sectors would experience a reduction in sales that partially offsets these impacts, the overall impact on job and income opportunities is positive. While the (-) payments to the energy suppliers may exactly match the sum of the $(+)$ payments to financial and insurance firms, state and local government, and the rest of the economy, the labor intensity of the economic activity associated with $(+)$ payments is larger than for the (-) payments.

Following the methodology outline in the next section, the impact analysis found that adoption of more aggressive residential building energy codes could create thousands of new jobs in construction and related industries in the states where they are implemented and save consumers hundreds of millions of dollars each year in utility bills in the long run, creating additional positive net long-term employment opportunities.

\section{A.3 Classifying Economic Impacts}

Economic impacts fall into three categories: direct, indirect, and induced. Direct impacts are the changes in the value of economic activity, employment, and employee income in the sectors experiencing changes in sales as an immediate result of investment and savings. Indirect impacts occur in industries that supply the sectors experiencing direct impacts. For example, a construction firm might experience a 
direct impact from investment, while its wholesale supplier or a fiberglass manufacturer would experience indirect impacts. Direct impacts of consumer spending of energy savings in the "rest of the economy" could occur in a wide variety of sectors, ranging from restaurants to furniture stores to barbershops, and similarly for indirect impacts. Finally, induced impacts occur as employees of directly and indirectly affected firms spend their additional earnings. The following sections summarize how PNNL conducted the analysis.

\section{A.3.1 Direct Impacts}

To estimate the direct impact of the required investment, PNNL first analyzed in detail the bill of labor and "materials" (the latter includes both purchased goods and business services) required to build prototype single-family and multifamily housing units in individual states under current and more energyefficient building energy codes. The required amounts of labor and materials generally increase with the level of energy efficiency desired. Examples of required labor include designers, construction workers, installers, and code enforcement personnel (plan review and inspection). Note that some of these may be provided as business services rather than direct hires by construction firms. Examples of required materials include such items as fenestration (windows, skylights and doors), insulation, ductwork and sealants, lighting fixtures, contracted services, etc. The bills of labor and materials analyzed by PNNL were the same as those used in the U.S. Department of Energy's cost-effectiveness analysis originally conducted in evaluating the 2012 International Energy Conservation Code (IECC) Residential Provisions compared with provisions of the 2009 and 2006 editions of the IECC applicable to residential buildings (DOE 2012). ${ }^{4}$ PNNL multiplied the differences in the costs of labor and materials for prototype residential buildings at the various energy code levels in the state by the number of housing starts in the state to obtain overall differences in the value of investment by economic sector that would be experienced from implementing the more recent editions of the IECC in that state. The amount of the difference in value of investment is the impact on investment final demand. In Taylor et al. 2012, PNNL included the mortgage amount, the down payment, and other upfront costs in the investment final demand. The same accounting was followed in this study.

To estimate the direct impact of energy savings associated with varying levels of energy efficiency associated with different editions of the IECC, PNNL first compiled the projected differences in annual consumption of natural gas, electricity, and fuel oil ${ }^{5}$ by end use for prototype residential buildings. These differences were determined in the 2012 cost-effectiveness analysis at each level of energy efficiency resultant from meeting the provisions of different editions of the IECC in each state (Taylor et al. 2012). PNNL then aggregated the differences by fuel, and multiplied by housing starts to obtain the statewide impacts. Energy savings were priced at prevailing residential prices in each state for the year 2011. The dollar value of the energy savings was assumed to be spent as follows. Following the PNNL costeffective analysis (Taylor et al. 2012), the researchers calculated the annual mortgage payment required to pay off the incremental mortgage cost for the more valuable ${ }^{6}$ housing unit over a period of 30 years at a mortgage interest rate of 5 percent. This study also adopted the PNNL (Taylor et al. 2012)-assumed increase in the annual property tax bill and the increase in property and mortgage insurance. Because the investment is cost-effective, these items add to less than the energy savings. The homeowner is assumed to spend the remainder of the projected savings in the same proportions as other consumer income earned in the state, yielding an estimate of increased consumer spending in several economic sectors as a result of the savings. The savings-related increased consumer spending within the state is the positive element of the impact on consumer savings-related final demand. ${ }^{7}$ 
To estimate the negative direct impact of reduced energy sales in a state, PNNL allocated the dollar value of energy savings (with a negative algebraic sign) as reduced sales by the natural gas utilities, electric utilities, and fuel oil suppliers in the state. ${ }^{8}$ This is the negative element of the impact on utility final demand. Generally speaking, gas and electric utilities and fuel oil suppliers are very capital intensive, with very few employees per million dollars of sales compared with other industries. Thus, changing the mix of consumer final demand from energy to other sectors generally increases the demand for labor, other things being equal.

\section{A.3.2 Indirect, Induced, and Total Impacts}

PNNL estimated the indirect and induced job impacts using the state-level version of IMPLAN, ${ }^{\circledR} \mathrm{a}$ widely accepted economic national and regional input-output model. ${ }^{9}$ IMPLAN is a product of MIG, Inc. (formerly Minnesota IMPLAN Group, Inc.), and contains detailed data on sales and purchases, employment, and related economic series. It shows quantitatively how a change in direct spending or employment in any of more than 400 sectors of the state economy requires changes in supporting economic output, employment, and earned income in all of the other sectors in the state (indirect impact). In addition, using consumer spending patterns, the IMPLAN model can track the subsequent spending of additional income paid to employees of the directly and indirectly affected sectors and can calculate the additional resulting impacts on economic output, employment, and income of that activity (induced impact). The sum of direct, indirect, and induced impacts on the value of economic output, employment, or income is called the total impact. MIG, Inc. can customize IMPLAN for any state, county, or other subnational region of interest in the United States. ${ }^{10}$ The model converts user-supplied estimates of final demand into impacts on indirect, induced, and total economic output, employment, and income. It is based on MIG's “social accounting” for economic relationships between industries and regions, and within the distribution chain for goods and services. Of particular interest in the current study is output from IMPLAN on the impact of investment final demand, consumer final demand, and utility final demand on state-level direct, indirect, induced, and total jobs.

The following sections show how PNNL estimated changes in final demand.

\section{A.4 Determine Values of Direct Investment by Sector}

PNNL used residential building investment data from Taylor et al. 2012 as a basis for estimating incremental investment cost. Table A.1 shows the required investment for an average housing unit (covering single-family and multifamily units, with the proportion of each varying by state) by climate zone in the national cost-effectiveness analysis (DOE 2012). State-level analyses have been produced and are available online at www.energycodes.gov/development/residential/iecc analysis/. Table A.2 shows the incremental costs for each level of residential building energy code adoption determined in PNNL's state-level supporting estimates of cost-effectiveness of the 2009 and 2012 IECC. Details of the cost-effectiveness methodology can be found in Taylor et al. 2012. Figure A.2 is a map of the U.S. climate zones, showing the zones affected in this report. 
Table A.1. Incremental Investment from More Efficient Building Energy Codes by U.S. Climate Zone

\begin{tabular}{cccc}
\hline $\begin{array}{c}\text { Climate } \\
\text { Zone }\end{array}$ & $\begin{array}{c}\text { Shift from 2006 IECC to 2009 } \\
\text { IECC (2011\$) }\end{array}$ & $\begin{array}{c}\text { Shift from 2006 IECC to 2012 } \\
\text { IECC (2011\$) }\end{array}$ & $\begin{array}{c}\text { Shift from 2009 IECC to } 2012 \\
\text { IECC (2011\$) }\end{array}$ \\
\hline 1 & 1,317 & 2,813 & 1,496 \\
2 & 1,223 & 2,841 & 1,618 \\
3 & 1,261 & 3,377 & 2,107 \\
4 & 555 & 2,314 & 1,759 \\
5 & 875 & 2,399 & 1,524 \\
6 & 922 & 3,405 & 2,484 \\
7 & 677 & 3,236 & 2,559 \\
8 & 950 & 4,704 & 3,763 \\
\hline
\end{tabular}

Source: Derived from Tables A.9, A.10, and A.11 in DOE 2012.

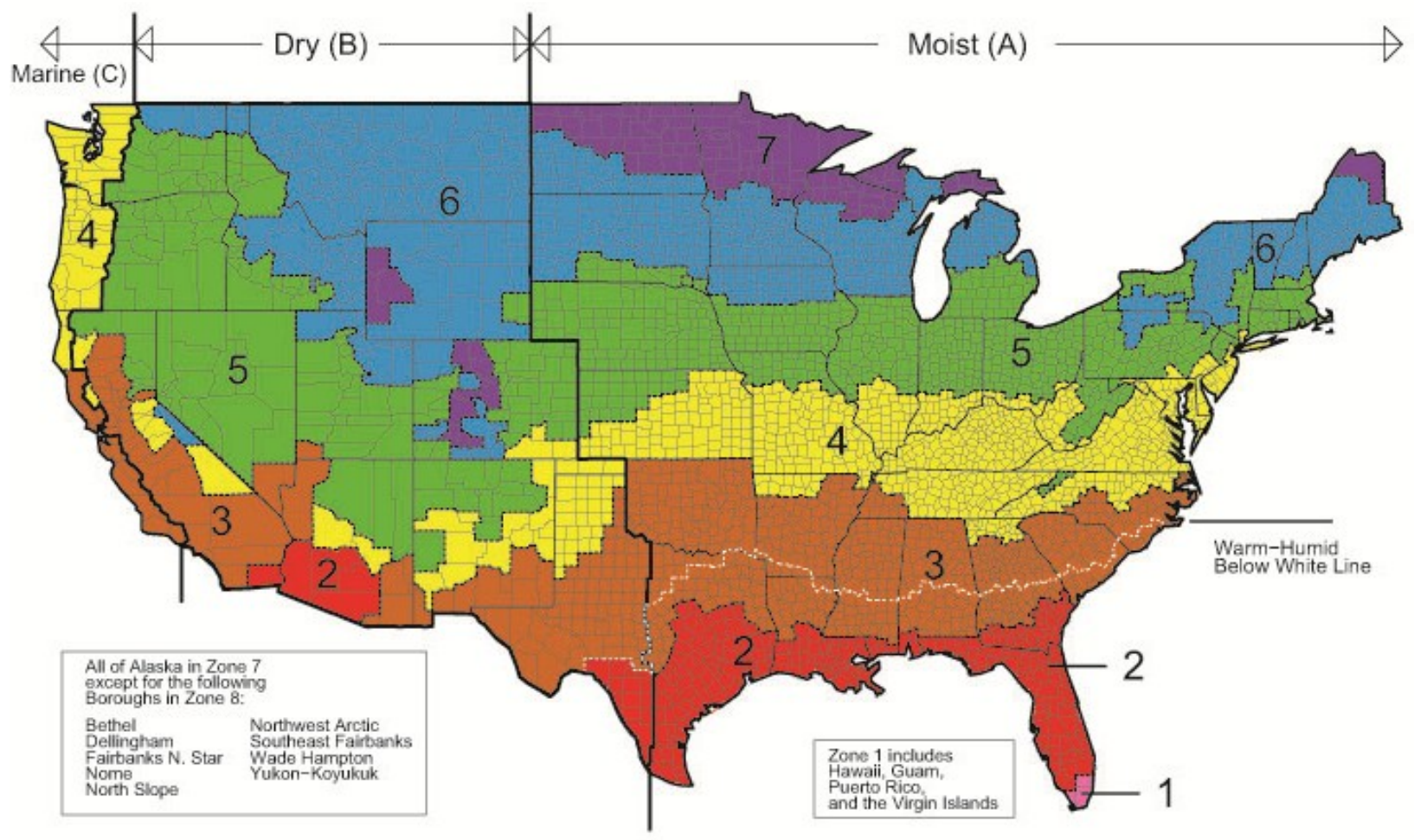

Figure A.2. Climate Zones of the United States 
These are the incremental investment costs that PNNL assumed would represent the additional payments to the general contractor and financial institutions to build an average housing unit to the provisions of the 2009 or 2012 IECC rather than to the 2006 IECC. To translate these costs into incremental payments, PNNL (Taylor et al. 2012) made the following assumptions about new home mortgages, which are also used in the current study:

- loan fees equal to 0.7 percent of the mortgage amount

- 30-year loan term, 5-percent interest rate ${ }^{11}$

- 10-percent down payment.

While in specific situations these assumptions may not be accurate, they are broadly representative of conditions in the mortgage industry. The construction sector experiences the investment cost as an increase in final demand; the financial sector receives the loan fees as a positive cash flow that represents an increase in final demand.

Investment payments are made to:

- construction sector: investment cost $(+)$

- financial sector: 0.7 percent $\times 90$ percent $\times$ investment cost $(+)$.

Once incremental payments by building energy code were determined, PNNL used construction permit data at the county level, allocated to the correct climate zone, to determine the effect on weighted average investment spending on a statewide level to meet the 2009 IECC and 2012 IECC. Residential permit data by county was compiled using data from the U.S. Department of Housing and Urban Development (HUD 2012). PNNL chose not to forecast housing starts into the future at this time, but rather used the most current data available to develop weighted average investment costs impacts based on the most recent year of complete data, which was 2010. Table A.2 shows the weighted average investment costs per unit based on the PNNL cost-effectiveness database for a series of state-level reports. ${ }^{12}$ About half of the states had adopted the residential provisions of the 2009 IECC residential code or an equivalent code by about August 2012; more than half of these adopted the IECC with modifications. For the states that had adopted the 2009 code or a variant of it, only the cost of moving from the 2009-2012 code matters, so no 2006-2009 or 2006-2012 estimate of the investment impact is shown in Table A.2. 
Table A.2. Weighted Average Incremental Residential Investment Costs per Average Unit, 2010 (2011\$)

\begin{tabular}{|c|c|c|c|c|c|c|c|}
\hline State & 2006-2009 & 2006-2012 & 2009-2012 & State & 2006-2009 & 2006-2012 & 2009-2012 \\
\hline Alabama & NA & NA & 1,891 & Nebraska & NA & NA & 1,336 \\
\hline Alaska & $922 \ddagger$ & 4,563 & 3,641 & Nevada & NA & NA & 2,427 \\
\hline Arizona & 1,317 & 3,123 & 1,806 & New Hampshire & NA & NA & $1,872 \ddagger$ \\
\hline Arkansas & 950 & 2,709 & 1,759 & New Jersey & NA & NA & $1,919 \ddagger$ \\
\hline California & NA & NA & $2,455 \ddagger$ & New Mexico & NA & NA & $1,787 \ddagger$ \\
\hline Colorado & 847 & 2,437 & 1,599 & New York & NA & NA & $1,863 \ddagger$ \\
\hline Connecticut & NA & NA & $1,684^{*}$ & North Carolina & NA & NA & $1,759 \ddagger$ \\
\hline Delaware & NA & NA & $2,060^{*}$ & North Dakota & 611 & 2,615 & 2,004 \\
\hline Florida & NA & NA & $1,609 \ddagger$ & Ohio & NA & NA & 1,496 \\
\hline Georgia & NA & NA & $2,004 \ddagger$ & Oklahoma & NA & NA & $2,437 \dagger$ \\
\hline Hawaii & $1,750 \ddagger$ & 3,706 & 1,957 & Oregon & NA & NA & $1,910 \ddagger$ \\
\hline Idaho & NA & NA & $1,731^{*}$ & Pennsylvania & NA & NA & 1,759 \\
\hline Illinois & NA & NA & $1,599 \ddagger$ & Rhode Island & NA & NA & 1,675 \\
\hline Indiana & NA & NA & $1,552 *$ & South Carolina & NA & NA & 1,985 \\
\hline Iowa & NA & NA & 1,627 & South Dakota & 781 & 2,813 & 2,023 \\
\hline Kansas & $517 *$ & 2,135 & 1,618 & Tennessee & 583 & 2,211 & 1,627 \\
\hline Kentucky & NA & NA & 1,731 & Texas & NA & NA & 1,665 \\
\hline Louisiana & $1,251 \ddagger$ & 3,010 & 1,759 & Utah & 856 & 2,437 & 1,580 \\
\hline Maine & NA & NA & $2,531 \ddagger$ & Vermont & NA & NA & $2,437 *$ \\
\hline Maryland & NA & NA & NA & Virginia & NA & NA & 2,023† \\
\hline Massachusetts & NA & NA & 1,684 & Washington & NA & NA & $1,825 \ddagger$ \\
\hline Michigan & NA & NA & $1,787^{*}$ & West Virginia & 677 & 2,371 & 1,693 \\
\hline Minnesota & $1,185 \dagger$ & 3,819 & 2,634 & Wisconsin & NA & NA & $2,446 \dagger$ \\
\hline Mississippi & 1,204 & 3,029 & 1,825 & Wyoming & 800 & 2,992 & 2,201 \\
\hline Missouri & 583 & 2,408 & 1,816 & Washington D.C. & NA & NA & $1,355 \neq$ \\
\hline Montana & NA & NA & $2,314+$ & & & & \\
\hline
\end{tabular}

Source: PNNL Cost-Effectiveness Database.

NA - not applicable. State already has adopted 2009 IECC or equivalent (Maryland has adopted 2012).

* State code slightly amends IECC code. Analysis used IECC.

†State code amends IECC. Custom state cost-effectiveness and custom analysis in this report.

$\ddagger$ State code amends IECC. No custom analysis available. Analysis used IECC.

Columns 2006-2009 and 2009-2012 may not add to 2006-2012 due to rounding errors in the underlying data.

The investment impacts can be scaled to any level in any state by simply assuming a level of housing starts in that state. To show how this assumption can affect total impact for a fixed distribution of housing starts across building types, Table A.3 summarizes the permit data used in the calculation of direct investment cost by state for 2010, contrasted with the average annual value for the period 20002010. 
Table A.3. Number of Residential Units Authorized by Permits by State, 2010, and Average Number 2000-2010

\begin{tabular}{|c|c|c|c|c|c|}
\hline State & $\begin{array}{l}2010 \text { Residential } \\
\text { Units Authorized }\end{array}$ & $\begin{array}{c}\text { 2010-2010 } \\
\text { Annual Average } \\
\text { Residential Units } \\
\text { Authorized }\end{array}$ & State & $\begin{array}{l}2010 \text { Residential } \\
\text { Units Authorized }\end{array}$ & $\begin{array}{c}\text { 2010-2010 } \\
\text { Annual Average } \\
\text { Residential Units } \\
\text { Authorized }\end{array}$ \\
\hline Alabama & 11,274 & 21,503 & Nebraska & 5,402 & 8,245 \\
\hline Alaska & 840 & 2,105 & Nevada & 6,372 & 30,223 \\
\hline Arizona & 12,367 & 56,924 & New Hampshire & 2,670 & 5,940 \\
\hline Arkansas & 7,177 & 11,717 & New Jersey & 13,535 & 27,712 \\
\hline California & 43,716 & 133,481 & New Mexico & 3,689 & 8,501 \\
\hline Colorado & 11,591 & 36,118 & New York & 19,565 & 45,654 \\
\hline Connecticut & 3,932 & 8,407 & North Carolina & 33,887 & 74,415 \\
\hline Delaware & 3,072 & 5,540 & North Dakota & 3,833 & 3,331 \\
\hline Florida & 38,679 & 155,025 & Ohio & 13,710 & 37,271 \\
\hline Georgia & 17,358 & 76,952 & Oklahoma & 8,140 & 13,213 \\
\hline Hawaii & 3,442 & 6,038 & Oregon & 6,783 & 19,792 \\
\hline Idaho & 4,149 & 12,355 & Pennsylvania & 19,743 & 36,784 \\
\hline Illinois & 12,318 & 45,886 & Rhode Island & 934 & 2,070 \\
\hline Indiana & 13,083 & 29,932 & South Carolina & 14,026 & 34,509 \\
\hline Iowa & 7,607 & 12,560 & South Dakota & 2,946 & 4,650 \\
\hline Kansas & 5,146 & 11,712 & Tennessee & 16,491 & 33,356 \\
\hline Kentucky & 7,965 & 16,129 & Texas & 87,736 & 152,988 \\
\hline Louisiana & 11,307 & 19,032 & Utah & 9,171 & 18,876 \\
\hline Maine & 2,933 & 6,097 & Vermont & 1,319 & 2,410 \\
\hline Maryland & 11,562 & 22,537 & Virginia & 15,710 & 35,971 \\
\hline Massachusetts & 9,075 & 16,511 & Washington & 20,691 & 39,064 \\
\hline Michigan & 8,994 & 34,394 & West Virginia & 2,395 & 4,387 \\
\hline Minnesota & 9,840 & 27,470 & Wisconsin & 10,909 & 28,523 \\
\hline Mississippi & 5,259 & 11,872 & Wyoming & 2,298 & 2,833 \\
\hline Missouri & 9,441 & 22,985 & Washington D.C. & 739 & 1,448 \\
\hline Montana & 2,022 & 3,370 & United States & 596,469 & $1,478,816$ \\
\hline
\end{tabular}

Source: HUD 2012.

PNNL multiplied the incremental investment costs for prototype residential buildings by residential housing units authorized by permits (housing starts) for 2010 to calculate statewide costs for the incremental investments that would have been needed to build all new residential buildings to meet the 2009 or 2012 IECC in 2010. The total investment costs needed as a direct result of new code adoption are shown in Table A.4 for the level of housing starts in 2010. Because 2010 was a severely depressed period for the housing market in almost all states, PNNL also calculated Table A.5, which shows the much larger level of incremental investment costs by state for the higher average level of housing starts during the period 2000-2010. 
Table A.4. Statewide Incremental Investment Costs to Meet 2009 IECC and 2012 IECC Residential Building Energy Codes by State in 2010

\begin{tabular}{|c|c|c|c|c|c|c|c|}
\hline \multicolumn{8}{|c|}{ Statewide Incremental Investment Costs (Thousand 2011\$) } \\
\hline State & 2006-2009 & 2006-2012 & 2009-2012 & State & 2006-2009 & 2006-2012 & 2009-2012 \\
\hline Alabama & NA & NA & 21,318 & Nebraska & NA & NA & 7,216 \\
\hline Alaska & $774 \ddagger$ & 3,833 & 3,058 & Nevada & NA & NA & 15,465 \\
\hline Arizona & 16,288 & 38,625 & 22,337 & New Hampshire & NA & NA & $4,998 \ddagger$ \\
\hline Arkansas & 6,819 & 19,445 & 12,626 & New Jersey & NA & NA & 25,975‡ \\
\hline California & NA & NA & $107,337 \ddagger$ & New Mexico & NA & NA & $6,594 \ddagger$ \\
\hline Colorado & 9,814 & 28,241 & 18,537 & New York & NA & NA & $36,443 \ddagger$ \\
\hline Connecticut & NA & NA & $6,621^{*}$ & North Carolina & NA & NA & $59,613 \ddagger$ \\
\hline Delaware & NA & NA & $6,329 *$ & North Dakota & 2,344 & 10,024 & 7,680 \\
\hline Florida & NA & NA & $62,221 \ddagger$ & Ohio & NA & NA & 20,507 \\
\hline Georgia & NA & NA & $34,781 \ddagger$ & Oklahoma & NA & NA & 19,833† \\
\hline Hawaii & $6,023 \ddagger$ & 12,758 & 6,735 & Oregon & NA & NA & $12,953 \ddagger$ \\
\hline Idaho & NA & NA & $7,182^{*}$ & Pennsylvania & NA & NA & 34,731 \\
\hline Illinois & NA & NA & $19,700 \ddagger$ & Rhode Island & NA & NA & 1,564 \\
\hline Indiana & NA & NA & $20,308^{*}$ & South Carolina & NA & NA & 27,841 \\
\hline Iowa & NA & NA & 12,380 & South Dakota & 2,300 & 8,286 & 5,959 \\
\hline Kansas & $2,663^{*}$ & 10,989 & 8,327 & Tennessee & 9,618 & 36,457 & 26,839 \\
\hline Kentucky & NA & NA & 13,787 & Texas & NA & NA & 146,089 \\
\hline Louisiana & $14,147 \ddagger$ & 34,038 & 19,891 & Utah & 7,851 & 22,345 & 14,494 \\
\hline Maine & NA & NA & $7,422 \ddagger$ & Vermont & NA & NA & $3,214^{*}$ \\
\hline Maryland & NA & NA & NA & Virginia & NA & NA & $31,775 \dagger$ \\
\hline Massachusetts & NA & NA & 15,282 & Washington & NA & NA & $37,762 \ddagger$ \\
\hline Michigan & NA & NA & $16,076^{*}$ & West Virginia & 1,622 & 5,678 & 4,056 \\
\hline Minnesota & $11,664 \dagger$ & 37,583 & 25,919 & Wisconsin & NA & NA & $26,682 \dagger$ \\
\hline Mississippi & 6,333 & 15,930 & 9,598 & Wyoming & 1,838 & 6,875 & 5,059 \\
\hline Missouri & 5,507 & 22,737 & 17,141 & Washington D.C. & NA & NA & $1,001 \ddagger$ \\
\hline Montana & NA & NA & $4,679 \ddagger$ & & & & \\
\hline
\end{tabular}

Source: PNNL Cost-Effectiveness Database.

NA - not applicable. State already has adopted 2009 IECC or equivalent (Maryland has adopted 2012).

* State code slightly amends IECC code. Analysis used IECC.

†State code amends IECC. Custom state cost-effectiveness and custom analysis in this report.

$\ddagger$ State code amends IECC. No custom analysis available. Analysis used IECC. 
Table A.5. Statewide Incremental Investment Costs to Meet 2009 IECC and 2012 IECC Residential Building Energy Codes by State at the Average Level of Housing Starts, 2000-2010

\begin{tabular}{|c|c|c|c|c|c|c|c|}
\hline \multicolumn{8}{|c|}{ Statewide Incremental Investment Costs (Thousand 2011\$) } \\
\hline State & 2006-2009 & 2006-2012 & 2009-2012 & State & 2006-2009 & 2006-2012 & 2009-2012 \\
\hline Alabama & NA & NA & 40,659 & Nebraska & NA & NA & 11,014 \\
\hline Alaska & $1,941 \ddagger$ & 9,604 & 7,664 & Nevada & NA & NA & 73,354 \\
\hline Arizona & 74,970 & 177,787 & 102,817 & New Hampshire & NA & NA & $11,120 \ddagger$ \\
\hline Arkansas & 11,133 & 31,745 & 20,612 & New Jersey & NA & NA & $53,182 \ddagger$ \\
\hline California & NA & NA & $327,738 \ddagger$ & New Mexico & NA & NA & $15,195 \ddagger$ \\
\hline Colorado & 30,580 & 88,002 & 57,762 & New York & NA & NA & $85,038 \neq$ \\
\hline Connecticut & NA & NA & $14,157 *$ & North Carolina & NA & NA & $130,909 \ddagger$ \\
\hline Delaware & NA & NA & $11,414 *$ & North Dakota & 2,037 & 8,711 & 6,675 \\
\hline Florida & NA & NA & $249,382 \ddagger$ & Ohio & NA & NA & 55,749 \\
\hline Georgia & NA & NA & $154,194 \ddagger$ & Oklahoma & NA & NA & $32,193 \dagger$ \\
\hline Hawaii & $10,565 \ddagger$ & 22,380 & 11,815 & Oregon & NA & NA & $37,797 \ddagger$ \\
\hline Idaho & NA & NA & $21,386 *$ & Pennsylvania & NA & NA & 64,709 \\
\hline Illinois & NA & NA & $73,383 \neq$ & Rhode Island & NA & NA & 3,466 \\
\hline Indiana & NA & NA & $46,461 *$ & South Carolina & NA & NA & 68,499 \\
\hline Iowa & NA & NA & 20,441 & South Dakota & 3,631 & 13,079 & 9,405 \\
\hline Kansas & $6,060 *$ & 25,011 & 18,951 & Tennessee & 19,455 & 73,741 & 54,286 \\
\hline Kentucky & NA & NA & 27,918 & Texas & NA & NA & 254,740 \\
\hline Louisiana & $23,812 \ddagger$ & 57,293 & 33,481 & Utah & 16,159 & 45,991 & 29,832 \\
\hline Maine & NA & NA & $15,429 \ddagger$ & Vermont & NA & NA & $5,872 *$ \\
\hline Maryland & NA & NA & NA & Virginia & NA & NA & $72,754 \dagger$ \\
\hline Massachusetts & NA & NA & 27,803 & Washington & NA & NA & 71,293‡ \\
\hline Michigan & NA & NA & 61,476* & West Virginia & 2,971 & 10,400 & 7,429 \\
\hline Minnesota & $32,561 \dagger$ & 104,918 & 72,357 & Wisconsin & NA & NA & $69,765 \dagger$ \\
\hline Mississippi & 14,296 & 35,962 & 21,667 & Wyoming & 2,265 & 8,475 & 6,236 \\
\hline Missouri & 13,406 & 55,354 & 41,732 & Washington D.C. & NA & NA & $1,962 \ddagger$ \\
\hline Montana & NA & NA & $7,799 \ddagger$ & & & & \\
\hline
\end{tabular}

Source: PNNL Cost-Effectiveness Database.

NA - not applicable. State already has adopted 2009 IECC or equivalent (Maryland has adopted 2012).

* State code slightly amends IECC code. Analysis used IECC.

†State code amends IECC. Custom state cost-effectiveness and custom analysis in this report.

$\ddagger$ State code amends IECC. No custom analysis available. Analysis used IECC.

The year 2010 and 2000-2010 investment cost values in Table A.4 and Table A.5 equal the increase in short-run payment flow (and final demand) to the construction sector in the given state. For the financial sector, the short-run increase payment flow (final demand ) equals 0.7 percent $\times 90$ percent $\times$ the 2010 or 2000-2010 average investment cost shown in Table A.4 and Table A.5 for any given state-a relatively minor amount. These two sources of change in final demand were used as inputs for the IMPLAN economic impact model, which calculated the short-term state-level investment-related employment impacts based on state-specific economic data and inter-industry relationships.

\section{A.5 Determine Direct Savings in Energy Expenditures}

Over the longer term, new building energy codes will generate energy savings. The reduced expenditures on energy increase consumers' disposable income, a large portion of which is spent in the local economy and can in turn create long-term jobs. 
To quantify the value of total residential consumer savings, PNNL multiplied the estimated savings in energy by energy type from the Building Energy Code Program's prototype building models by corresponding state-level fuel prices. Total consumer savings were calculated by multiplying energy savings data for each building type by climate zone in each state, given the appropriate proportion of housing starts of each building type in each climate zone in each state for 2010 (Taylor et al. 2012). Table A.6, Table A.7, and Table A.8 show the estimated mean dollar cost savings for electricity, natural gas, and fuel oil per housing unit in each state that were used to calculate total residential cost savings. This must be done by fuel, because the mix of fuels, end uses, and building types varies by climate zone (Taylor et al. 2012). In addition, fuel prices vary by state. Because many states show only small proportions of some fuels in some end uses, the mean savings per housing unit for a given fuel in a given state can be very small. For example, only the northeastern states have significant amounts of fuel oil heating and only they show significant mean fuel oil savings per housing unit. On the other hand, while a given housing unit in Minnesota actually heated with fuel oil would show significant savings, the small proportion of units heated with fuel oil in Minnesota yields a very small average value for fuel oil savings per housing unit in that state. The savings numbers for each state were multiplied by the estimated permits in each state to calculate total residential cost savings for electricity, natural gas, and fuel oil for that state. The total savings are shown in Appendix B. 
Table A.6. Mean Value of Annual Electricity Savings per Housing Unit by State by Building Energy Code Increase

\begin{tabular}{|c|c|c|c|c|c|c|c|}
\hline \multicolumn{8}{|c|}{ Mean Value of Annual Electricity Savings per Housing Unit (2011\$) } \\
\hline State & 2006-2009 & 2006-2012 & 2009-2012 & State & 2006-2009 & 2006-2012 & 2009-2012 \\
\hline Alabama & NA & NA & 225 & Nebraska & NA & NA & 193 \\
\hline Alaska & $237 \ddagger$ & 827 & 590 & Nevada & NA & NA & 201 \\
\hline Arizona & 207 & 371 & 164 & New Hampshire & NA & NA & $140 \ddagger$ \\
\hline Arkansas & 113 & 320 & 207 & New Jersey & NA & NA & $232 \ddagger$ \\
\hline California & NA & NA & $88 \ddagger$ & New Mexico & NA & NA & $131 \ddagger$ \\
\hline Colorado & 71 & 185 & 114 & New York & NA & NA & $264 \ddagger$ \\
\hline Connecticut & NA & NA & $143 *$ & North Carolina & NA & NA & $246 \ddagger$ \\
\hline Delaware & NA & NA & $525 *$ & North Dakota & 97 & 342 & 245 \\
\hline Florida & NA & NA & $157 \ddagger$ & Ohio & NA & NA & 129 \\
\hline Georgia & NA & NA & $257 \ddagger$ & Oklahoma & NA & NA & $295 \dagger$ \\
\hline Hawaii & $346 \ddagger$ & 898 & 552 & Oregon & NA & NA & $101 \ddagger$ \\
\hline Idaho & NA & NA & $92 *$ & Pennsylvania & NA & NA & 214 \\
\hline Illinois & NA & NA & $149 \ddagger$ & Rhode Island & NA & NA & 127 \\
\hline Indiana & NA & NA & $135 *$ & South Carolina & NA & NA & 274 \\
\hline Iowa & NA & NA & 280 & South Dakota & 114 & 378 & 264 \\
\hline Kansas & $106^{*}$ & 347 & 241 & Tennessee & 106 & 341 & 235 \\
\hline Kentucky & NA & NA & 275 & Texas & NA & NA & 199 \\
\hline Louisiana & $133 \ddagger$ & 282 & 149 & Utah & 65 & 159 & 94 \\
\hline Maine & NA & NA & $164 \ddagger$ & Vermont & NA & NA & $157^{*}$ \\
\hline Maryland & NA & NA & NA & Virginia & NA & NA & $331 \dagger$ \\
\hline Massachusetts & NA & NA & 116 & Washington & NA & NA & $101 \ddagger$ \\
\hline Michigan & NA & NA & $220 *$ & West Virginia & 119 & 414 & 295 \\
\hline Minnesota & $91 \dagger$ & 428 & 337 & Wisconsin & NA & NA & $228 \dagger$ \\
\hline Mississippi & 151 & 362 & 211 & Wyoming & 62 & 180 & 118 \\
\hline Missouri & 89 & 289 & 200 & Washington, D.C. & NA & NA & $266 \ddagger$ \\
\hline Montana & NA & NA & $117 \ddagger$ & & & & \\
\hline
\end{tabular}

Source: PNNL Cost-Effectiveness Database.

NA - not applicable. State already has adopted 2009 IECC or equivalent (Maryland has adopted 2012).

* State code slightly amends IECC code. Analysis used IECC.

†State code amends IECC. Custom state cost-effectiveness and custom analysis in this report.

$\ddagger$ State code amends IECC. No custom analysis available. Analysis used IECC. 
Table A.7. Mean Value of Annual Natural Gas Savings per Housing Unit by State by Building Energy Code Increase

\begin{tabular}{|c|c|c|c|c|c|c|c|}
\hline \multicolumn{8}{|c|}{ Mean Value of Annual Natural Gas Savings per Housing Unit (2011\$) } \\
\hline State & 2006-2009 & 2006-2012 & 2009-2012 & State & 2006-2009 & 2006-2012 & 2009-2012 \\
\hline Alabama & NA & NA & 69 & Nebraska & NA & NA & 129 \\
\hline Alaska & $102 \ddagger$ & 426 & 324 & Nevada & NA & NA & 159 \\
\hline Arizona & 22 & 113 & 91 & New Hampshire & NA & NA & $249 \ddagger$ \\
\hline Arkansas & 30 & 135 & 105 & New Jersey & NA & NA & $242 \ddagger$ \\
\hline California & NA & NA & $80 \ddagger$ & New Mexico & NA & NA & $157 \ddagger$ \\
\hline Colorado & 49 & 208 & 159 & New York & NA & NA & $266 \ddagger$ \\
\hline Connecticut & NA & NA & $215^{*}$ & North Carolina & NA & NA & $41 \ddagger$ \\
\hline Delaware & NA & NA & $88^{*}$ & North Dakota & 52 & 218 & 166 \\
\hline Florida & NA & NA & $15 \ddagger$ & Ohio & NA & NA & 200 \\
\hline Georgia & NA & NA & $49 \ddagger$ & Oklahoma & NA & NA & $109 \dagger$ \\
\hline Hawaii & $0 \ddagger$ & 0 & 0 & Oregon & NA & NA & $160 \ddagger$ \\
\hline Idaho & NA & NA & $195 *$ & Pennsylvania & NA & NA & 264 \\
\hline Illinois & NA & NA & $166 \ddagger$ & Rhode Island & NA & NA & 257 \\
\hline Indiana & NA & NA & $188^{*}$ & South Carolina & NA & NA & 41 \\
\hline Iowa & NA & NA & 173 & South Dakota & 54 & 230 & 176 \\
\hline Kansas & $49 *$ & 195 & 146 & Tennessee & 17 & 72 & 55 \\
\hline Kentucky & NA & NA & 73 & Texas & NA & NA & 53 \\
\hline Louisiana & $16 \ddagger$ & 75 & 59 & Utah & 48 & 205 & 157 \\
\hline Maine & NA & NA & $340 \ddagger$ & Vermont & NA & NA & $340^{*}$ \\
\hline Maryland & NA & NA & NA & Virginia & NA & NA & $56 \dagger$ \\
\hline Massachusetts & NA & NA & 265 & Washington & NA & NA & $178 \ddagger$ \\
\hline Michigan & NA & NA & $311^{*}$ & West Virginia & 16 & 66 & 50 \\
\hline Minnesota & $31 \dagger$ & 240 & 209 & Wisconsin & NA & NA & $294 \dagger$ \\
\hline Mississippi & 13 & 58 & 45 & Wyoming & 67 & 285 & 218 \\
\hline Missouri & 52 & 213 & 161 & Washington, D.C. & NA & NA & $40 \ddagger$ \\
\hline Montana & NA & NA & $205 \ddagger$ & & & & \\
\hline
\end{tabular}

Source: PNNL Cost-Effectiveness Database.

NA - not applicable. State already has adopted 2009 IECC or equivalent (Maryland has adopted 2012).

* State code slightly amends IECC code. Analysis used IECC.

$\dagger$ State code amends IECC. Custom state cost-effectiveness and custom analysis in this report.

$¥$ State code amends IECC. No custom analysis available. Analysis used IECC. 
Table A.8. Mean Value of Annual Fuel Oil Savings per Housing Unit by State by Building Energy Code Increase

\begin{tabular}{|c|c|c|c|c|c|c|c|}
\hline \multicolumn{8}{|c|}{ Mean Value of Annual Fuel Oil Savings per Housing Unit (2011\$) } \\
\hline State & 2006-2009 & 2006-2012 & 2009-2012 & State & 2006-2009 & 2006-2012 & 2009-2012 \\
\hline Alabama & NA & NA & 0 & Nebraska & NA & NA & 1 \\
\hline Alaska & $0 \ddagger$ & 3 & 3 & Nevada & NA & NA & 1 \\
\hline Arizona & 0 & 0 & 0 & New Hampshire & NA & NA & $230 \ddagger$ \\
\hline Arkansas & 0 & 0 & 0 & New Jersey & NA & NA & $30 \ddagger$ \\
\hline California & NA & NA & $0 \ddagger$ & New Mexico & NA & NA & $1 \ddagger$ \\
\hline Colorado & 0 & 1 & 1 & New York & NA & NA & $34 \ddagger$ \\
\hline Connecticut & NA & NA & $217 *$ & North Carolina & NA & NA & $0 \ddagger$ \\
\hline Delaware & NA & NA & $1 *$ & North Dakota & 1 & 2 & 1 \\
\hline Florida & NA & NA & $1 \ddagger$ & Ohio & NA & NA & 3 \\
\hline Georgia & NA & NA & $0 \neq$ & Oklahoma & NA & NA & $0 \dagger$ \\
\hline Hawaii & $0 \ddagger$ & 0 & 0 & Oregon & NA & NA & $1 \ddagger$ \\
\hline Idaho & NA & NA & $1^{*}$ & Pennsylvania & NA & NA & 37 \\
\hline Illinois & NA & NA & $4 \ddagger$ & Rhode Island & NA & NA & 244 \\
\hline Indiana & NA & NA & $4^{*}$ & South Carolina & NA & NA & 0 \\
\hline Iowa & NA & NA & 2 & South Dakota & 1 & 3 & 2 \\
\hline Kansas & $0^{*}$ & 1 & 1 & Tennessee & 0 & 0 & 0 \\
\hline Kentucky & NA & NA & 0 & Texas & NA & NA & 0 \\
\hline Louisiana & $0 \ddagger$ & 0 & 0 & Utah & 1 & 2 & 1 \\
\hline Maine & NA & NA & $298 \ddagger$ & Vermont & NA & NA & $295^{*}$ \\
\hline Maryland & NA & NA & NA & Virginia & NA & NA & $1 \dagger$ \\
\hline Massachusetts & NA & NA & 243 & Washington & NA & NA & $1 \ddagger$ \\
\hline Michigan & NA & NA & $5^{*}$ & West Virginia & 0 & 1 & 1 \\
\hline Minnesota & $1 \dagger$ & 2 & 1 & Wisconsin & NA & NA & $5 \dagger$ \\
\hline Mississippi & 0 & 0 & 0 & Wyoming & 0 & 2 & 2 \\
\hline Missouri & 0 & 2 & 2 & Washington, D.C. & NA & NA & $0 \ddagger$ \\
\hline Montana & NA & NA & $2 \ddagger$ & & & & \\
\hline
\end{tabular}

Source: PNNL Cost-Effectiveness Database.

NA - not applicable. State already has adopted 2009 IECC or equivalent (Maryland has adopted 2012).

* State code slightly amends IECC code. Analysis used IECC.

†State code amends IECC. Custom state cost-effectiveness and custom analysis in this report.

$\ddagger$ State code amends IECC. No custom analysis available. Analysis used IECC.

\section{A.6 Determine Consumer Direct Payment Flows from Energy Savings}

Calculating energy savings is only the first step in calculating the long-term payment flows associated with building energy codes. While the homeowner enjoys reduced energy costs, at the same time he or she must begin to repay the incremental mortgage and insurance costs and incremental property taxes required for the more efficient but more valuable building. The values and methods for calculating the payment flows were previously used to calculate life-cycle cost and cash flows (Taylor et al. 2012). The estimated consumer payments in this section came from the database underlying that report. Although energy savings are experienced as losses in final demand by the utility and fuel oil supply sectors, they are experienced simultaneously by households, as increases in disposable household income. This increased disposable income is spent by homeowners to pay back the incremental cost of the mortgage and insurance on the more efficient (but more expensive) housing unit, and to pay the incremental property taxes on the more efficient (but more valuable) housing unit. Therefore, the finance, 
insurance, and state and local government sectors experience an increase in final demand. Finally, adjusted for income tax deductions at the federal and state level, the remaining disposable income is assumed to be spent like any other income in the rest of the economy, which also experiences an increase in final demand in the IMPLAN model.

In fact, as the housing stock expands over time, the value of savings expands with it. While the shortterm economic effects occur only in the year of construction, the longer-term effects of the energy savings persist as long as the more efficient stock remains in the housing inventory and expand with the size of the accumulated efficient housing stock.

Much of this spending will occur outside of the state. The IMPLAN methodology compensates by allowing for a spending "leakage" out of the state economy in the form of imported goods and services. This is because not all energy savings necessarily would be spent locally. For example, any expenditures of household savings on out-of-state catalog- and internet-based purchases, out-of-state shopping, and expenditures while on out-of-state travel would not cause an increase in in-state final demand. The direction of the impact on in-state final demand is shown below as “+,” “-,” or “0.”

1. Energy savings by households:

electric utility sales (-), natural gas utility sales (-), fuel oil supplier sales (-)

2. Payments by households ( $\mathrm{a}+\mathrm{b}+\mathrm{c}+\mathrm{d}$ must sum to energy savings):

a. to financial sector: 90 percent $\times$ investment cost $(+) \times$ annualization factor for 30 -year mortgage at 5 percent

b. to insurance sector: mortgage insurance, an amount that varies locally but is between 6.6 percent and 9.6 percent of the mortgage payment

c. to state and local government: property tax rate (assumed to be 0.9 percent) $\times$ investment cost $\times$ (1 - income tax rate) $(+)$

d. to other in-state final demand: locally spent portion of (energy savings - payments for mortgage, insurance, and property taxes, less deductions) $(+)$

e. to other out-of-state final demand: IMPLAN only counts the local component of final demand for the state forecast (0).

The sources of change in final demand (items 1, 2a, 2b, 2c, and 2d in the list above) were used as inputs for the IMPLAN economic impact model. This model was used to calculate the long-term statelevel employment impacts based on state-specific economic data and inter-industry relationships from any one year of housing sales that meet the newer editions of building energy codes. These components of long-term consumer payments out of energy savings are fed into IMPLAN final demand, and then IMPLAN calculates the resulting long-term direct, indirect, and induced employment impacts. Table A.9 through Table A.12 show the average per-unit cost for incremental mortgage cost, property taxes, and insurance, and the offsetting value of tax savings from deductibility. 
Table A.9. Average Incremental Mortgage Payments per Housing Unit to Meet the 2009 and 2012 IECC Building Energy Codes

\begin{tabular}{|c|c|c|c|c|c|c|c|}
\hline \multicolumn{8}{|c|}{ Average Incremental Mortgage Payments Per Housing Unit (2011\$) } \\
\hline State & 2006-2009 & 2006-2012 & 2009-2012 & State & 2006-2009 & 2006-2012 & 2009-2012 \\
\hline Alabama & NA & NA & 109 & Nebraska & NA & NA & 77 \\
\hline Alaska & $53 \ddagger$ & 263 & 210 & Nevada & NA & NA & 140 \\
\hline Arizona & 76 & 180 & 104 & New Hampshire & NA & NA & $108 \ddagger$ \\
\hline Arkansas & 55 & 156 & 101 & New Jersey & NA & NA & $110 \ddagger$ \\
\hline California & NA & NA & $141 \ddagger$ & New Mexico & NA & NA & $103 \ddagger$ \\
\hline Colorado & 49 & 141 & 92 & New York & NA & NA & $107 \ddagger$ \\
\hline Connecticut & NA & NA & $97 *$ & North Carolina & NA & NA & $101 \ddagger$ \\
\hline Delaware & NA & NA & 119* & North Dakota & 35 & 151 & 115 \\
\hline Florida & NA & NA & $93 \ddagger$ & Ohio & NA & NA & 86 \\
\hline Georgia & NA & NA & $116 \ddagger$ & Oklahoma & NA & NA & $140 \dagger$ \\
\hline Hawaii & $101 \ddagger$ & 214 & 113 & Oregon & NA & NA & $110 \ddagger$ \\
\hline Idaho & NA & NA & $100 *$ & Pennsylvania & NA & NA & 101 \\
\hline Illinois & NA & NA & $92 \ddagger$ & Rhode Island & NA & NA & 97 \\
\hline Indiana & NA & NA & $89 *$ & South Carolina & NA & NA & 114 \\
\hline Iowa & NA & NA & 94 & South Dakota & 45 & 162 & 117 \\
\hline Kansas & $30 *$ & 123 & 93 & Tennessee & 34 & 127 & 94 \\
\hline Kentucky & NA & NA & 100 & Texas & NA & NA & 96 \\
\hline Louisiana & $72 \ddagger$ & 174 & 102 & Utah & 49 & 140 & 91 \\
\hline Maine & NA & NA & $146 \ddagger$ & Vermont & NA & NA & $141^{*}$ \\
\hline Maryland & NA & NA & NA & Virginia & NA & NA & $117 \dagger$ \\
\hline Massachusetts & NA & NA & 97 & Washington & NA & NA & $105 \ddagger$ \\
\hline Michigan & NA & NA & $103 *$ & West Virginia & 39 & 137 & 98 \\
\hline Minnesota & $68 \dagger$ & 220 & 152 & Wisconsin & NA & NA & $141 \dagger$ \\
\hline Mississippi & 69 & 175 & 105 & Wyoming & 46 & 172 & 127 \\
\hline Missouri & 34 & 138 & 105 & Washington D.C. & NA & NA & $78 \ddagger$ \\
\hline Montana & NA & NA & $133 \ddagger$ & & & & \\
\hline
\end{tabular}

Source: PNNL Cost-Effectiveness Database.

NA - not applicable. State already has adopted 2009 IECC or equivalent (Maryland has adopted 2012).

* State code slightly amends IECC code. Analysis used IECC.

†State code amends IECC. Custom state cost-effectiveness and custom analysis in this report.

$¥$ State code amends IECC. No custom analysis available. Analysis used IECC. 
Table A.10. Average Incremental Property Tax Payments per Housing Unit to Meet the 2009 and 2012 IECC Building Energy Codes

\begin{tabular}{|c|c|c|c|c|c|c|c|}
\hline \multicolumn{8}{|c|}{ Average Incremental Property Tax Payments Per Housing Unit (2011\$) } \\
\hline State & 2006-2009 & 2006-2012 & 2009-2012 & State & 2006-2009 & 2006-2012 & 2009-2012 \\
\hline Alabama & NA & NA & 17 & Nebraska & NA & NA & 12 \\
\hline Alaska & $8 \ddagger$ & 41 & 33 & Nevada & NA & NA & 22 \\
\hline Arizona & 12 & 28 & 16 & New Hampshire & NA & NA & $17 \ddagger$ \\
\hline Arkansas & 9 & 25 & 16 & New Jersey & NA & NA & $17 \ddagger$ \\
\hline California & NA & NA & $22 \ddagger$ & New Mexico & NA & NA & $16 \ddagger$ \\
\hline Colorado & 8 & 22 & 15 & New York & NA & NA & $17 \ddagger$ \\
\hline Connecticut & NA & NA & $15^{*}$ & North Carolina & NA & NA & $16 \ddagger$ \\
\hline Delaware & NA & NA & $19 *$ & North Dakota & 6 & 24 & 18 \\
\hline Florida & NA & NA & $15 \ddagger$ & Ohio & NA & NA & 14 \\
\hline Georgia & NA & NA & $18 \ddagger$ & Oklahoma & NA & NA & $22 \dagger$ \\
\hline Hawaii & $16 \ddagger$ & 34 & 18 & Oregon & NA & NA & $17 \ddagger$ \\
\hline Idaho & NA & NA & $16^{*}$ & Pennsylvania & NA & NA & 16 \\
\hline Illinois & NA & NA & $15 \ddagger$ & Rhode Island & NA & NA & 15 \\
\hline Indiana & NA & NA & $14 *$ & South Carolina & NA & NA & 18 \\
\hline Iowa & NA & NA & 15 & South Dakota & 7 & 26 & 18 \\
\hline Kansas & $5^{*}$ & 19 & 15 & Tennessee & 5 & 20 & 15 \\
\hline Kentucky & NA & NA & 16 & Texas & NA & NA & 15 \\
\hline Louisiana & $11 \ddagger$ & 27 & 16 & Utah & 8 & 22 & 14 \\
\hline Maine & NA & NA & $23 \ddagger$ & Vermont & NA & NA & $22^{*}$ \\
\hline Maryland & NA & NA & NA & Virginia & NA & NA & $18 \dagger$ \\
\hline Massachusetts & NA & NA & 15 & Washington & NA & NA & $17 \ddagger$ \\
\hline Michigan & NA & NA & $16^{*}$ & West Virginia & 6 & 22 & 15 \\
\hline Minnesota & $11 \dagger$ & 35 & 24 & Wisconsin & NA & NA & $22 \dagger$ \\
\hline Mississippi & 11 & 28 & 17 & Wyoming & 7 & 27 & 20 \\
\hline Missouri & 5 & 22 & 17 & Washington D.C. & NA & NA & $12 \ddagger$ \\
\hline Montana & NA & NA & $21 \ddagger$ & & & & \\
\hline
\end{tabular}

Source: PNNL Cost-Effectiveness Database.

NA - not applicable. State already has adopted 2009 IECC or equivalent (Maryland has adopted 2012).

* State code slightly amends IECC code. Analysis used IECC.

†State code amends IECC. Custom state cost-effectiveness and custom analysis in this report.

$\ddagger$ State code amends IECC. No custom analysis available. Analysis used IECC. 
Table A.11. Average Incremental Insurance Payments per Housing Unit to Meet the 2009 and 2012 IECC Building Energy Codes

\begin{tabular}{|c|c|c|c|c|c|c|c|}
\hline \multicolumn{8}{|c|}{ Average Incremental Insurance Payments Per Housing Unit (2011\$) } \\
\hline State & 2006-2009 & 2006-2012 & 2009-2012 & State & 2006-2009 & 2006-2012 & 2009-2012 \\
\hline Alabama & NA & NA & 9 & Nebraska & NA & NA & 6 \\
\hline Alaska & $4 \ddagger$ & 21 & 17 & Nevada & NA & NA & 11 \\
\hline Arizona & 6 & 15 & 8 & New Hampshire & NA & NA & $9 \ddagger$ \\
\hline Arkansas & 4 & 13 & 8 & New Jersey & NA & NA & $9 \ddagger$ \\
\hline California & NA & NA & $11 \ddagger$ & New Mexico & NA & NA & $8 \ddagger$ \\
\hline Colorado & 4 & 11 & 7 & New York & NA & NA & $9 \ddagger$ \\
\hline Connecticut & NA & NA & $8 *$ & North Carolina & NA & NA & $8 \ddagger$ \\
\hline Delaware & NA & NA & $10 *$ & North Dakota & 3 & 12 & 9 \\
\hline Florida & NA & NA & $7 \ddagger$ & Ohio & NA & NA & 7 \\
\hline Georgia & NA & NA & $9 \ddagger$ & Oklahoma & NA & NA & $11 \dagger$ \\
\hline Hawaii & $8 \ddagger$ & 17 & 9 & Oregon & NA & NA & $9 \ddagger$ \\
\hline Idaho & NA & NA & $8^{*}$ & Pennsylvania & NA & NA & 8 \\
\hline Illinois & NA & NA & $7 \ddagger$ & Rhode Island & NA & NA & 8 \\
\hline Indiana & NA & NA & 7* & South Carolina & NA & NA & 9 \\
\hline Iowa & NA & NA & 8 & South Dakota & 4 & 13 & 9 \\
\hline Kansas & $2 *$ & 10 & 8 & Tennessee & 3 & 10 & 8 \\
\hline Kentucky & NA & NA & 8 & Texas & NA & NA & 8 \\
\hline Louisiana & 6‡ & 14 & 8 & Utah & 4 & 11 & 7 \\
\hline Maine & NA & NA & $12 \ddagger$ & Vermont & NA & NA & $11^{*}$ \\
\hline Maryland & NA & NA & NA & Virginia & NA & NA & $9 \dagger$ \\
\hline Massachusetts & NA & NA & 8 & Washington & NA & NA & $8 \ddagger$ \\
\hline Michigan & NA & NA & $8^{*}$ & West Virginia & 3 & 11 & 8 \\
\hline Minnesota & $6 \dagger$ & 18 & 12 & Wisconsin & NA & NA & $11 \dagger$ \\
\hline Mississippi & 6 & 14 & 8 & Wyoming & 4 & 14 & 10 \\
\hline Missouri & 3 & 11 & 8 & Washington D.C. & NA & NA & $6 \ddagger$ \\
\hline Montana & NA & NA & $11 \ddagger$ & & & & \\
\hline
\end{tabular}

Source: PNNL Cost-Effectiveness Database.

NA - not applicable. State already has adopted 2009 IECC or equivalent (Maryland has adopted 2012).

* State code slightly amends IECC code. Analysis used IECC.

†State code amends IECC. Custom state cost-effectiveness and custom analysis in this report.

$\ddagger$ State code amends IECC. No custom analysis available. Analysis used IECC. 
Table A.12. Average Incremental Tax Deductions per Housing Unit to Meet the 2009 and 2012 IECC Building Energy Codes

\begin{tabular}{|c|c|c|c|c|c|c|c|}
\hline \multicolumn{8}{|c|}{ Average Incremental Tax Deductions Per Housing Unit (2011\$) } \\
\hline State & 2006-2009 & 2006-2012 & 2009-2012 & State & 2006-2009 & 2006-2012 & 2009-2012 \\
\hline Alabama & NA & NA & 25 & Nebraska & NA & NA & 19 \\
\hline Alaska & $10 \ddagger$ & 51 & 40 & Nevada & NA & NA & 27 \\
\hline Arizona & 17 & 40 & 23 & New Hampshire & NA & NA & $21 \ddagger$ \\
\hline Arkansas & 14 & 38 & 25 & New Jersey & NA & NA & $24 \ddagger$ \\
\hline California & NA & NA & $37 \ddagger$ & New Mexico & NA & NA & $24 \ddagger$ \\
\hline Colorado & 11 & 32 & 21 & New York & NA & NA & $26 \ddagger$ \\
\hline Connecticut & NA & NA & $23 *$ & North Carolina & NA & NA & $25 \ddagger$ \\
\hline Delaware & NA & NA & $29 *$ & North Dakota & 7 & 32 & 25 \\
\hline Florida & NA & NA & $18 \ddagger$ & Ohio & NA & NA & 19 \\
\hline Georgia & NA & NA & $28 \ddagger$ & Oklahoma & NA & NA & $33 \dagger$ \\
\hline Hawaii & $26 \ddagger$ & 55 & 29 & Oregon & NA & NA & $29 \ddagger$ \\
\hline Idaho & NA & NA & $25^{*}$ & Pennsylvania & NA & NA & 22 \\
\hline Illinois & NA & NA & $21 \ddagger$ & Rhode Island & NA & NA & 22 \\
\hline Indiana & NA & NA & $19 *$ & South Carolina & NA & NA & 28 \\
\hline Iowa & NA & NA & 25 & South Dakota & 9 & 31 & 22 \\
\hline Kansas & 7* & 30 & 22 & Tennessee & 7 & 24 & 18 \\
\hline Kentucky & NA & NA & 24 & Texas & NA & NA & 18 \\
\hline Louisiana & $17 \ddagger$ & 41 & 24 & Utah & 11 & 32 & 21 \\
\hline Maine & NA & NA & NA $\ddagger$ & Vermont & NA & NA & $34^{*}$ \\
\hline Maryland & NA & NA & 23 & Virginia & NA & NA & $28 \dagger$ \\
\hline Massachusetts & NA & NA & 23 & Washington & NA & NA & $20 \ddagger$ \\
\hline Michigan & NA & NA & $23^{*}$ & West Virginia & 9 & 33 & 24 \\
\hline Minnesota & $17 \dagger$ & 54 & 37 & Wisconsin & NA & NA & $34 \dagger$ \\
\hline Mississippi & 16 & 40 & 24 & Wyoming & 9 & 33 & 24 \\
\hline Missouri & 8 & 33 & 25 & Washington D.C. & NA & NA & $20 \ddagger$ \\
\hline Montana & NA & NA & $33 \ddagger$ & & & & \\
\hline
\end{tabular}

Source: PNNL Cost-Effectiveness Database.

NA - not applicable. State already has adopted 2009 IECC or equivalent (Maryland has adopted 2012).

* State code slightly amends IECC code. Analysis used IECC.

†State code amends IECC. Custom state cost-effectiveness and custom analysis in this report.

$\ddagger$ State code amends IECC. No custom analysis available. Analysis used IECC.

\section{A.7 Conclusion}

PNNL determined total employment and labor income impacts of implementing the residential provisions of the 2009 and 2012 IECC building energy codes in each analyzed state by aggregating all three categories of job creation (direct, indirect, induced) produced by the IMPLAN input-output model of the state's economy. The inputs for the IMPLAN model runs were estimated for all states by analyzing data used by PNNL to calculate the cost-effectiveness in 2010 of building energy code upgrades from the 2006 IECC to the 2009 version, from the 2006 to the 2012 version, and from the 2009 to the 2012 version as applicable to residential buildings. PNNL used the cost-effectiveness data to calculate short-term and long-term financial flows associated with each edition of the IECC in each state, reported in Appendix B. Because 2010 was a depressed year in the housing market of nearly every state, and therefore likely was not representative of "normal" conditions in the housing market, PNNL not only calculated impacts for 2010 level of housing starts but also for the average of the period 2000-2010, a more representative time 
period. The total employment impacts appear in Table 2 in the main report. For more information on building energy codes, please visit www.energycodes.gov.

\section{A.8 References}

DOE - U.S. Department of Energy. 2012. National Energy and Cost Savings for New Single- and Multifamily Homes: A Comparison of the 2006, 2009, and 2012 Editions of the International Energy Conservation Code. Building Energy Codes Program, Washington, D.C.

HUD - U.S. Department of Housing and Urban Development. 2012. SOCDS Building Permits Database. Washington, D.C. Accessed June 9, 2012 at http://socds.huduser.org/permits/help.htm.

Taylor ZT, N Fernandez, and RG Lucas. 2012. Methodology for Evaluating Cost-Effectiveness of Residential Energy Code Changes. PNNL-21294, Pacific Northwest National Laboratory, Richland, Washington. Accessed June 9, 2012 at http://www.energycodes.gov/sites/default/files/documents/residential_methodology.pdf.

\footnotetext{
${ }^{1}$ While the impacts are not covered in the report, the building energy codes also apply to some elements of residential additions, renovations, and alterations.

${ }^{2}$ Final demand (also sometimes known as final use) is a term in economics referring to household consumption, government consumption and investment, private investment, and exports. In modeling an economy, changes in final demand (e.g., an increase in the demand for housing), leads to production of goods and services to satisfy that demand and to additional direct and indirect economic activity.

${ }^{3}$ Figure A.1 shows the typical homeowner and single family, cooperative, or condominium situation, where the homeowner both takes out a mortgage to build the house (or equivalently, takes out a mortgage to buy the housing unit from the developer), bears the cost of subsequent mortgage payments, and pays any energy bills. In the rental situation, the building owner uses rental payments to retire the mortgage and pay property taxes, and the renter pays the energy bills directly or indirectly through the rental payment or a "condo fee." From an economic impact perspective, the payments go to approximately the same places - the construction costs, the financial and insurance costs, energy suppliers, and state and local government. Any energy savings after these costs are paid are available to the homeowner or renter to purchase other goods and services. The differences in impact between the owner and renter situation are minor and have been ignored.

${ }^{4}$ Where necessary, the original published analysis was augmented with additional engineering judgments made by PNNL staff engineers in support of the cost-effectiveness study.

${ }^{5}$ The methods in Taylor et al. used three heating fuels and that method has been carried over to this report. The energy cost savings in this study would have been slightly higher if liquefied petroleum gasses (LPG) had been included, since LPG is generally more expensive than fuel oil on a per-Btu basis.

${ }^{6}$ The assumption here is that the additional investment in the housing unit will be reflected at cost in its assessed value.

${ }^{7}$ PNNL recognizes that some consumer expenditures may be made in states other than the home state. The economic model used in this study accounts for these economic leakages as spending on "imports."

${ }^{8}$ PNNL assumed that the initial impact would be on local suppliers.

${ }^{9}$ IMPLAN Version 3.0. Hudson, WI: MIG, Inc. Computer software.

${ }^{10}$ This requires the purchase of MIG's input-output data set for the region of interest.

${ }^{11}$ We are aware that some of the housing units constructed may be covered by programs under the U.S. Department of Housing and Urban Development, the Farmers Home Administration, the U.S. Department of Veterans Affairs, and other federal agencies as well as state agencies that may have more stringent energy efficiency criteria and/or different financing considerations. Those were not broken out here because the energy efficiency criteria are generally over and above minimum state or local codes, and the focus of this report is on the benefits associated with meeting the minimum code. In addition, special financing considerations would not substantively change the overall
} 
payment flows although they may divide responsibility for payment between the homeowner or renter and a government agency. Five percent is a higher rate than current mortgage rates in early 2013, but is consistent with plausible longer-term averages for inflation-adjusted mortgage rates of 3.0 to 3.5 percent and target inflation rates of about 1.5 to 2.0 percent.

${ }^{12}$ The reports are posted to the DOE Building Energy Codes Program website at http://www.energycodes.gov/development/residential/iecc_analysis/. 


\section{Appendix B}

\section{Long-Term Statewide Savings and Cost Data}





\section{Appendix B}

\section{Long-Term Statewide Savings and Cost Data}

Pacific Northwest National Laboratory (PNNL) estimated the overall statewide level of costs and savings experienced from meeting the 2009 International Energy Conservation Code (IECC) as applicable to residential buildings and 2012 IECC Residential Provisions by multiplying cost and savings data for average housing units in each state by corresponding numbers of residential housing starts from Table A.3. This appendix contains the statewide values.

In section B.1, Table B.1 through Table B.3 show the value of statewide energy savings by energy type for the 2010 level of housing starts. Section B.2 reports the corresponding long-term consumer payments to final demand out of those savings in Table B.4 through Table B.7. In section B.3, Table B.8 through Table B.10 show the value of statewide energy savings by energy type at the 2000-2010 average level of housing starts. Section B.4 reports the corresponding long-term consumer payments to final demand out of those savings in Table B.11 through Table B.14. 


\section{B.1 Long-Term Value of Energy Savings at 2010 Level of Housing Starts}

Table B.1. Statewide Value of Annual Electricity Savings per Housing Unit by State by Building Energy Code Increase, 2010 Level of Housing Starts

\begin{tabular}{|c|c|c|c|c|c|c|c|}
\hline \multicolumn{8}{|c|}{ Statewide Value of Annual Electricity Savings (Thousand 2011\$) } \\
\hline State & 2006-2009 & 2006-2012 & 2009-2012 & State & 2006-2009 & 2006-2012 & 2009-2012 \\
\hline Alabama & NA & NA & 2,537 & Nebraska & NA & NA & 1,043 \\
\hline Alaska & $199 \ddagger$ & 695 & 496 & Nevada & NA & NA & 1,281 \\
\hline Arizona & 2,560 & 4,588 & 2,028 & New Hampshire & NA & NA & $374 \ddagger$ \\
\hline Arkansas & 811 & 2,297 & 1,486 & New Jersey & NA & NA & $3,140 \ddagger$ \\
\hline California & NA & NA & $3,847 \ddagger$ & New Mexico & NA & NA & $483 \ddagger$ \\
\hline Colorado & 823 & 2,144 & 1,321 & New York & NA & NA & $5,165 \ddagger$ \\
\hline Connecticut & NA & NA & $562 *$ & North Carolina & NA & NA & $8,336 \neq$ \\
\hline Delaware & NA & NA & $1,613^{*}$ & North Dakota & 372 & 1,311 & 939 \\
\hline Florida & NA & NA & $6,073 \ddagger$ & Ohio & NA & NA & 1,769 \\
\hline Georgia & NA & NA & $4,461 \ddagger$ & Oklahoma & NA & NA & $2,401 \dagger$ \\
\hline Hawaii & $1,191 \ddagger$ & 3,091 & 1,900 & Oregon & NA & NA & $685 \ddagger$ \\
\hline Idaho & NA & NA & $382^{*}$ & Pennsylvania & NA & NA & 4,225 \\
\hline Illinois & NA & NA & $1,835 \ddagger$ & Rhode Island & NA & NA & 119 \\
\hline Indiana & NA & NA & $1,766^{*}$ & South Carolina & NA & NA & 3,843 \\
\hline Iowa & NA & NA & 2,130 & South Dakota & 336 & 1,114 & 778 \\
\hline Kansas & $545^{*}$ & 1,786 & 1,240 & Tennessee & 1,748 & 5,623 & 3,875 \\
\hline Kentucky & NA & NA & 2,190 & Texas & NA & NA & 17,459 \\
\hline Louisiana & $1,504 \ddagger$ & 3,189 & 1,685 & Utah & 596 & 1,458 & 862 \\
\hline Maine & NA & NA & $481 \ddagger$ & Vermont & NA & NA & $207 *$ \\
\hline Maryland & NA & NA & NA & Virginia & NA & NA & $5,200 \dagger$ \\
\hline Massachusetts & NA & NA & 1,053 & Washington & NA & NA & $2,090 \ddagger$ \\
\hline Michigan & NA & NA & $1,979 *$ & West Virginia & 285 & 992 & 707 \\
\hline Minnesota & $895 \dagger$ & 4,212 & 3,316 & Wisconsin & NA & NA & $2,487 \dagger$ \\
\hline Mississippi & 794 & 1,904 & 1,110 & Wyoming & 142 & 414 & 271 \\
\hline Missouri & 840 & 2,728 & 1,888 & Washington, D.C. & NA & NA & $197 \ddagger$ \\
\hline Montana & NA & NA & $237 \ddagger$ & & & & \\
\hline
\end{tabular}

Source: PNNL Cost-Effectiveness Database.

NA - not applicable. State already has adopted 2009 IECC or equivalent (Maryland has adopted 2012).

* State code slightly amends IECC code. Analysis used IECC.

†State code amends IECC. Custom state cost-effectiveness and custom analysis in this report.

$\ddagger$ State code amends IECC. No custom analysis available. Analysis used IECC. 
Table B.2. Statewide Value of Annual Natural Gas Savings by State by Building Energy Code Increase, 2010 Level of Housing Starts

\begin{tabular}{|c|c|c|c|c|c|c|c|}
\hline \multicolumn{8}{|c|}{ Statewide Value of Annual Natural Gas Savings (Thousand 2011\$) } \\
\hline State & 2006-2009 & 2006-2012 & 2009-2012 & State & 2006-2009 & 2006-2012 & 2009-2012 \\
\hline Alabama & NA & NA & 778 & Nebraska & NA & NA & 697 \\
\hline Alaska & $86 \ddagger$ & 358 & 272 & Nevada & NA & NA & 1,013 \\
\hline Arizona & 272 & 1,397 & 1,125 & New Hampshire & NA & NA & $665 \ddagger$ \\
\hline Arkansas & 215 & 969 & 754 & New Jersey & NA & NA & $3,275 \ddagger$ \\
\hline California & NA & NA & $3,497 \ddagger$ & New Mexico & NA & NA & $579 \ddagger$ \\
\hline Colorado & 568 & 2,411 & 1,843 & New York & NA & NA & $5,204 \ddagger$ \\
\hline Connecticut & NA & NA & $845^{*}$ & North Carolina & NA & NA & $1,389 \ddagger$ \\
\hline Delaware & NA & NA & $270^{*}$ & North Dakota & 199 & 836 & 636 \\
\hline Florida & NA & NA & $580 \ddagger$ & Ohio & NA & NA & 2,742 \\
\hline Georgia & NA & NA & $851 \ddagger$ & Oklahoma & NA & NA & $887 \dagger$ \\
\hline Hawaii & $0 \ddagger$ & 0 & 0 & Oregon & NA & NA & $1,085 \ddagger$ \\
\hline Idaho & NA & NA & $809 *$ & Pennsylvania & NA & NA & 5,212 \\
\hline Illinois & NA & NA & $2,045 \ddagger$ & Rhode Island & NA & NA & 240 \\
\hline Indiana & NA & NA & $2,460 *$ & South Carolina & NA & NA & 575 \\
\hline Iowa & NA & NA & 1,316 & South Dakota & 159 & 678 & 518 \\
\hline Kansas & $252 *$ & 1,003 & 751 & Tennessee & 280 & 1,187 & 907 \\
\hline Kentucky & NA & NA & 581 & Texas & NA & NA & 4,650 \\
\hline Louisiana & $181 \ddagger$ & 848 & 667 & Utah & 440 & 1,880 & 1,440 \\
\hline Maine & NA & NA & $997 \ddagger$ & Vermont & NA & NA & $448^{*}$ \\
\hline Maryland & NA & NA & NA & Virginia & NA & NA & $880 \dagger$ \\
\hline Massachusetts & NA & NA & 2,405 & Washington & NA & NA & $3,683 \ddagger$ \\
\hline Michigan & NA & NA & $2,797 *$ & West Virginia & 38 & 158 & 120 \\
\hline Minnesota & $305 \dagger$ & 2,362 & 2,057 & Wisconsin & NA & NA & $3,207 \dagger$ \\
\hline Mississippi & 68 & 305 & 237 & Wyoming & 154 & 655 & 501 \\
\hline Missouri & 491 & 2,011 & 1,520 & Washington, D.C. & NA & NA & $30 \ddagger$ \\
\hline Montana & NA & NA & $415 \ddagger$ & & & & \\
\hline
\end{tabular}

Source: PNNL Cost-Effectiveness Database.

NA - not applicable. State already has adopted 2009 IECC or equivalent (Maryland has adopted 2012).

* State code slightly amends IECC code. Analysis used IECC.

†State code amends IECC. Custom state cost-effectiveness and custom analysis in this report.

$¥$ State code amends IECC. No custom analysis available. Analysis used IECC. 
Table B.3. Statewide Value of Annual Fuel Oil Savings by State by Building Energy Code Increase, 2010 Level of Housing Starts

\begin{tabular}{|c|c|c|c|c|c|c|c|}
\hline \multicolumn{8}{|c|}{ Statewide Value of Annual Fuel Oil Savings (Thousand 2011\$) } \\
\hline State & 2006-2009 & 2006-2012 & 2009-2012 & State & 2006-2009 & 2006-2012 & 2009-2012 \\
\hline Alabama & NA & NA & 0 & Nebraska & NA & NA & 5 \\
\hline Alaska & $0 \ddagger$ & 3 & 3 & Nevada & NA & NA & 6 \\
\hline Arizona & 0 & 0 & 0 & New Hampshire & NA & NA & $614 \ddagger$ \\
\hline Arkansas & 0 & 0 & 0 & New Jersey & NA & NA & $406 \ddagger$ \\
\hline California & NA & NA & $0 \ddagger$ & New Mexico & NA & NA & $4 \ddagger$ \\
\hline Colorado & 0 & 12 & 12 & New York & NA & NA & $665 \ddagger$ \\
\hline Connecticut & NA & NA & $853 *$ & North Carolina & NA & NA & $0 \ddagger$ \\
\hline Delaware & NA & NA & $3^{*}$ & North Dakota & 4 & 8 & 4 \\
\hline Florida & NA & NA & $39 \ddagger$ & Ohio & NA & NA & 41 \\
\hline Georgia & NA & NA & $0 \ddagger$ & Oklahoma & NA & NA & $0 \dagger$ \\
\hline Hawaii & $0 \ddagger$ & 0 & 0 & Oregon & NA & NA & $7 \ddagger$ \\
\hline Idaho & NA & NA & $4^{*}$ & Pennsylvania & NA & NA & 730 \\
\hline Illinois & NA & NA & $49 \ddagger$ & Rhode Island & NA & NA & 228 \\
\hline Indiana & NA & NA & $52 *$ & South Carolina & NA & NA & 0 \\
\hline Iowa & NA & NA & 15 & South Dakota & 3 & 9 & 6 \\
\hline Kansas & $0 *$ & 5 & 5 & Tennessee & 0 & 0 & 0 \\
\hline Kentucky & NA & NA & 0 & Texas & NA & NA & 0 \\
\hline Louisiana & $0 \ddagger$ & 0 & 0 & Utah & 9 & 18 & 9 \\
\hline Maine & NA & NA & $874 \ddagger$ & Vermont & NA & NA & $389 *$ \\
\hline Maryland & NA & NA & NA & Virginia & NA & NA & $16 \dagger$ \\
\hline Massachusetts & NA & NA & 2,205 & Washington & NA & NA & $21 \ddagger$ \\
\hline Michigan & NA & NA & $45^{*}$ & West Virginia & 0 & 2 & 2 \\
\hline Minnesota & $10 \dagger$ & 20 & 10 & Wisconsin & NA & NA & $55 \dagger$ \\
\hline Mississippi & 0 & 0 & 0 & Wyoming & 0 & 5 & 5 \\
\hline Missouri & 0 & 19 & 19 & Washington, D.C. & NA & NA & $0 \ddagger$ \\
\hline Montana & NA & NA & $4 \ddagger$ & & & & \\
\hline
\end{tabular}

Source: PNNL Cost-Effectiveness Database.

NA - not applicable. State already has adopted 2009 IECC or equivalent (Maryland has adopted 2012).

* State code slightly amends IECC code. Analysis used IECC.

†State code amends IECC. Custom state cost-effectiveness and custom analysis in this report.

$¥$ State code amends IECC. No custom analysis available. Analysis used IECC. 


\section{B.2 Long-Term Consumer Spending of Energy Savings at 2010 Level of Housing Starts}

Table B.4. Statewide Incremental Mortgage Payments to Meet the 2009 and 2012 IECC Building Energy Codes, Housing Starts Equal to 2010 Level

\begin{tabular}{|c|c|c|c|c|c|c|c|}
\hline \multicolumn{8}{|c|}{ Statewide Incremental Mortgage Payments (Thousand 2011\$) } \\
\hline State & 2006-2009 & 2006-2012 & 2009-2012 & State & 2006-2009 & 2006-2012 & 2009-2012 \\
\hline Alabama & NA & NA & 1,229 & Nebraska & NA & NA & 416 \\
\hline Alaska & $45 \ddagger$ & 221 & 176 & Nevada & NA & NA & 892 \\
\hline Arizona & 940 & 2,226 & 1,286 & New Hampshire & NA & NA & $288 \ddagger$ \\
\hline Arkansas & 395 & 1,120 & 725 & New Jersey & NA & NA & $1,489 \ddagger$ \\
\hline California & NA & NA & $6,164 \ddagger$ & New Mexico & NA & NA & $380 \ddagger$ \\
\hline Colorado & 568 & 1,634 & 1,066 & New York & NA & NA & $2,093 \ddagger$ \\
\hline Connecticut & NA & NA & $381 *$ & North Carolina & NA & NA & $3,423 \ddagger$ \\
\hline Delaware & NA & NA & $366 *$ & North Dakota & 134 & 579 & 441 \\
\hline Florida & NA & NA & $3,597 \ddagger$ & Ohio & NA & NA & 1,179 \\
\hline Georgia & NA & NA & $2,014 \ddagger$ & Oklahoma & NA & NA & $1,140 \dagger$ \\
\hline Hawaii & $348 \neq$ & 737 & 389 & Oregon & NA & NA & $746 \ddagger$ \\
\hline Idaho & NA & NA & $415^{*}$ & Pennsylvania & NA & NA & 1,994 \\
\hline Illinois & NA & NA & $1,133 \ddagger$ & Rhode Island & NA & NA & 91 \\
\hline Indiana & NA & NA & $1,164 *$ & South Carolina & NA & NA & 1,599 \\
\hline Iowa & NA & NA & 715 & South Dakota & 133 & 477 & 345 \\
\hline Kansas & $154 *$ & 633 & 479 & Tennessee & 561 & 2,094 & 1,550 \\
\hline Kentucky & NA & NA & 797 & Texas & NA & NA & 8,423 \\
\hline Louisiana & $814 \ddagger$ & 1,967 & 1,153 & Utah & 449 & 1,284 & 835 \\
\hline Maine & NA & NA & $428 \ddagger$ & Vermont & NA & NA & $186 *$ \\
\hline Maryland & NA & NA & NA & Virginia & NA & NA & 1,838† \\
\hline Massachusetts & NA & NA & 880 & Washington & NA & NA & $2,173 \ddagger$ \\
\hline Michigan & NA & NA & $926 *$ & West Virginia & 93 & 328 & 235 \\
\hline Minnesota & $669 \dagger$ & 2,165 & 1,496 & Wisconsin & NA & NA & $1,538 \dagger$ \\
\hline Mississippi & 363 & 920 & 552 & Wyoming & 106 & 395 & 292 \\
\hline Missouri & 321 & 1,303 & 991 & Washington D.C. & NA & NA & $58 \ddagger$ \\
\hline Montana & NA & NA & $269 \ddagger$ & & & & \\
\hline
\end{tabular}

Source: PNNL Cost-Effectiveness Database.

NA - not applicable. State already has adopted 2009 IECC or equivalent (Maryland has adopted 2012).

* State code slightly amends IECC code. Analysis used IECC.

†State code amends IECC. Custom state cost-effectiveness and custom analysis in this report.

$¥$ State code amends IECC. No custom analysis available. Analysis used IECC. 
Table B.5. Statewide Incremental Property Tax Payments to Meet the 2009 and 2012 IECC Building Energy Codes, Housing Starts Equal to 2010 Level

\begin{tabular}{|c|c|c|c|c|c|c|c|}
\hline \multicolumn{8}{|c|}{ Statewide Incremental Property Tax Payments (Thousand 2011\$) } \\
\hline State & 2006-2009 & 2006-2012 & 2009-2012 & State & 2006-2009 & 2006-2012 & 2009-2012 \\
\hline Alabama & NA & NA & 192 & Nebraska & NA & NA & 65 \\
\hline Alaska & $7 \ddagger$ & 34 & 28 & Nevada & NA & NA & 140 \\
\hline Arizona & 148 & 346 & 198 & New Hampshire & NA & NA & $45 \ddagger$ \\
\hline Arkansas & 65 & 179 & 115 & New Jersey & NA & NA & $230 \ddagger$ \\
\hline California & NA & NA & $962 \ddagger$ & New Mexico & NA & NA & $59 \ddagger$ \\
\hline Colorado & 93 & 255 & 174 & New York & NA & NA & $333 \ddagger$ \\
\hline Connecticut & NA & NA & 59* & North Carolina & NA & NA & $542 \ddagger$ \\
\hline Delaware & NA & NA & $58 *$ & North Dakota & 23 & 92 & 69 \\
\hline Florida & NA & NA & $580 \ddagger$ & Ohio & NA & NA & 192 \\
\hline Georgia & NA & NA & $312 \ddagger$ & Oklahoma & NA & NA & $179 \dagger$ \\
\hline Hawaii & $55 \ddagger$ & 117 & 62 & Oregon & NA & NA & $115 \ddagger$ \\
\hline Idaho & NA & NA & $66^{*}$ & Pennsylvania & NA & NA & 316 \\
\hline Illinois & NA & NA & $185 \ddagger$ & Rhode Island & NA & NA & 14 \\
\hline Indiana & NA & NA & $183 *$ & South Carolina & NA & NA & 252 \\
\hline Iowa & NA & NA & 114 & South Dakota & 21 & 77 & 53 \\
\hline Kansas & $26 *$ & 98 & 77 & Tennessee & 82 & 330 & 247 \\
\hline Kentucky & NA & NA & 127 & Texas & NA & NA & 1,316 \\
\hline Louisiana & $124 \ddagger$ & 305 & 181 & Utah & 73 & 202 & 128 \\
\hline Maine & NA & NA & $67 \ddagger$ & Vermont & NA & NA & $29 *$ \\
\hline Maryland & NA & NA & NA & Virginia & NA & NA & $283 \dagger$ \\
\hline Massachusetts & NA & NA & 136 & Washington & NA & NA & $352 \ddagger$ \\
\hline Michigan & NA & NA & $144 *$ & West Virginia & 14 & 53 & 36 \\
\hline Minnesota & $108 \dagger$ & 344 & 236 & Wisconsin & NA & NA & $240 \dagger$ \\
\hline Mississippi & 58 & 147 & 89 & Wyoming & 16 & 62 & 46 \\
\hline Missouri & 47 & 208 & 160 & Washington D.C. & NA & NA & $9 \ddagger$ \\
\hline Montana & NA & NA & $42 \ddagger$ & & & & \\
\hline
\end{tabular}

Source: PNNL Cost-Effectiveness Database.

NA - not applicable. State already has adopted 2009 IECC or equivalent (Maryland has adopted 2012).

* State code slightly amends IECC code. Analysis used IECC.

†State code amends IECC. Custom state cost-effectiveness and custom analysis in this report.

$¥$ State code amends IECC. No custom analysis available. Analysis used IECC. 
Table B.6. Statewide Incremental Insurance Payments to Meet the 2009 and 2012 IECC Building Energy Codes, Housing Starts Equal to 2010 Level

\begin{tabular}{|c|c|c|c|c|c|c|c|}
\hline \multicolumn{8}{|c|}{ Statewide Incremental Insurance Payments (Thousand 2011\$) } \\
\hline State & 2006-2009 & 2006-2012 & 2009-2012 & State & 2006-2009 & 2006-2012 & 2009-2012 \\
\hline Alabama & NA & NA & 101 & Nebraska & NA & NA & 32 \\
\hline Alaska & $3 \ddagger$ & 18 & 14 & Nevada & NA & NA & 70 \\
\hline Arizona & 74 & 186 & 99 & New Hampshire & NA & NA & $24 \ddagger$ \\
\hline Arkansas & 29 & 93 & 57 & New Jersey & NA & NA & $122 \ddagger$ \\
\hline California & NA & NA & $481 \ddagger$ & New Mexico & NA & NA & $30 \ddagger$ \\
\hline Colorado & 46 & 128 & 81 & New York & NA & NA & $176 \ddagger$ \\
\hline Connecticut & NA & NA & $31^{*}$ & North Carolina & NA & NA & 271‡ \\
\hline Delaware & NA & NA & $31 *$ & North Dakota & 11 & 46 & 34 \\
\hline Florida & NA & NA & $271 \ddagger$ & Ohio & NA & NA & 96 \\
\hline Georgia & NA & NA & $156 \ddagger$ & Oklahoma & NA & NA & $90 \dagger$ \\
\hline Hawaii & $28 \ddagger$ & 59 & 31 & Oregon & NA & NA & $61 \ddagger$ \\
\hline Idaho & NA & NA & $33 *$ & Pennsylvania & NA & NA & 158 \\
\hline Illinois & NA & NA & $86 \ddagger$ & Rhode Island & NA & NA & 7 \\
\hline Indiana & NA & NA & $92 *$ & South Carolina & NA & NA & 126 \\
\hline Iowa & NA & NA & 61 & South Dakota & 12 & 38 & 27 \\
\hline Kansas & $10^{*}$ & 51 & 41 & Tennessee & 49 & 165 & 132 \\
\hline Kentucky & NA & NA & 64 & Texas & NA & NA & 702 \\
\hline Louisiana & $68 \ddagger$ & 158 & 90 & Utah & 37 & 101 & 64 \\
\hline Maine & NA & NA & $35 \ddagger$ & Vermont & NA & NA & $15^{*}$ \\
\hline Maryland & NA & NA & NA & Virginia & NA & NA & $141 \dagger$ \\
\hline Massachusetts & NA & NA & 73 & Washington & NA & NA & $166 \ddagger$ \\
\hline Michigan & NA & NA & $72 *$ & West Virginia & 7 & 26 & 19 \\
\hline Minnesota & $59 \dagger$ & 177 & 118 & Wisconsin & NA & NA & $120 \dagger$ \\
\hline Mississippi & 32 & 74 & 42 & Wyoming & 9 & 32 & 23 \\
\hline Missouri & 28 & 104 & 76 & Washington D.C. & NA & NA & $4 \ddagger$ \\
\hline Montana & NA & NA & $22 \ddagger$ & & & & \\
\hline
\end{tabular}

Source: PNNL Cost-Effectiveness Database.

NA - not applicable. State already has adopted 2009 IECC or equivalent (Maryland has adopted 2012).

* State code slightly amends IECC code. Analysis used IECC.

†State code amends IECC. Custom state cost-effectiveness and custom analysis in this report.

$¥$ State code amends IECC. No custom analysis available. Analysis used IECC. 
Table B.7. Other Statewide Consumer Spending Out of Energy Savings from Meeting the 2009 and 2012 IECC Building Energy Codes, Housing Starts Equal to 2010 Level

\begin{tabular}{|c|c|c|c|c|c|c|c|}
\hline \multicolumn{8}{|c|}{ Other Statewide Consumer Spending Out of Energy Savings (Thousand 2011\$) } \\
\hline State & 2006-2009 & 2006-2012 & 2009-2012 & State & 2006-2009 & 2006-2012 & 2009-2012 \\
\hline Alabama & NA & NA & 2,074 & Nebraska & NA & NA & 1,345 \\
\hline Alaska & $239 \ddagger$ & 821 & 580 & Nevada & NA & NA & 1,364 \\
\hline Arizona & 1,905 & 3,747 & 1,855 & New Hampshire & NA & NA & $1,143 \ddagger$ \\
\hline Arkansas & 667 & 2,225 & 1,572 & New Jersey & NA & NA & $5,400 \ddagger$ \\
\hline California & NA & NA & $1,268 \ddagger$ & New Mexico & NA & NA & $682 \ddagger$ \\
\hline Colorado & 800 & 2,898 & 2,086 & New York & NA & NA & $9,137 \ddagger$ \\
\hline Connecticut & NA & NA & $1,876^{*}$ & North Carolina & NA & NA & $5,862 \ddagger$ \\
\hline Delaware & NA & NA & $1,527 *$ & North Dakota & 429 & 1,552 & 1,127 \\
\hline Florida & NA & NA & $2,940 \ddagger$ & Ohio & NA & NA & 3,318 \\
\hline Georgia & NA & NA & $3,315 \ddagger$ & Oklahoma & NA & NA & $2,182 \dagger$ \\
\hline Hawaii & $854 \ddagger$ & 2,365 & 1,511 & Oregon & NA & NA & $712 \ddagger$ \\
\hline Idaho & NA & NA & $772 *$ & Pennsylvania & NA & NA & 8,134 \\
\hline Illinois & NA & NA & $2,710 \ddagger$ & Rhode Island & NA & NA & 496 \\
\hline Indiana & NA & NA & $3,048 *$ & South Carolina & NA & NA & 2,497 \\
\hline Iowa & NA & NA & 2,754 & South Dakota & 356 & 1,293 & 940 \\
\hline Kansas & $643^{*}$ & 2,166 & 1,513 & Tennessee & 1,451 & 4,650 & 3,183 \\
\hline Kentucky & NA & NA & 1,983 & Texas & NA & NA & 13,862 \\
\hline Louisiana & 871‡ & 2,080 & 1,210 & Utah & 569 & 2,036 & 1,467 \\
\hline Maine & NA & NA & $1,927 \ddagger$ & Vermont & NA & NA & $860 *$ \\
\hline Maryland & NA & NA & NA & Virginia & NA & NA & $4,273 \dagger$ \\
\hline Massachusetts & NA & NA & 4,755 & Washington & NA & NA & $3,517 \ddagger$ \\
\hline Michigan & NA & NA & $3,849 *$ & West Virginia & 230 & 821 & 594 \\
\hline Minnesota & $531 \dagger$ & 4,428 & 3,897 & Wisconsin & NA & NA & $4,178 \dagger$ \\
\hline Mississippi & 494 & 1,288 & 799 & Wyoming & 191 & 657 & 464 \\
\hline Missouri & 1,029 & 3,484 & 2,445 & Washington D.C. & NA & NA & $168 \ddagger$ \\
\hline Montana & NA & NA & $378 \ddagger$ & & & & \\
\hline
\end{tabular}

Source: PNNL Cost-Effectiveness Database.

NA - not applicable. State already has adopted 2009 IECC or equivalent (Maryland has adopted 2012).

* State code slightly amends IECC code. Analysis used IECC.

†State code amends IECC. Custom state cost-effectiveness and custom analysis in this report.

$¥$ State code amends IECC. No custom analysis available. Analysis used IECC. 


\section{B.3 Long-Term Value of Energy Savings at the 2000-2010 Average Level of Housing Starts}

Table B.8. Statewide Value of Annual Electricity Savings per Housing Unit by State by Building Energy Code Upgrade, 2000-2010 Average Level of Housing Starts

\begin{tabular}{|c|c|c|c|c|c|c|c|}
\hline \multicolumn{8}{|c|}{ Statewide Value of Annual Electricity Savings (Thousand 2011\$) } \\
\hline State & 2006-2009 & 2006-2012 & 2009-2012 & State & 2006-2009 & 2006-2012 & 2009-2012 \\
\hline Alabama & NA & NA & 4,838 & Nebraska & NA & NA & 1,591 \\
\hline Alaska & $499 \ddagger$ & 1,741 & 1,242 & Nevada & NA & NA & 6,075 \\
\hline Arizona & 11,783 & 21,119 & 9,336 & New Hampshire & NA & NA & $832 \ddagger$ \\
\hline Arkansas & 1,324 & 3,749 & 2,425 & New Jersey & NA & NA & $6,429 \ddagger$ \\
\hline California & NA & NA & $11,746 \ddagger$ & New Mexico & NA & NA & $1,114 \ddagger$ \\
\hline Colorado & 2,564 & 6,682 & 4,117 & New York & NA & NA & $12,053 \ddagger$ \\
\hline Connecticut & NA & NA & $1,202 *$ & North Carolina & NA & NA & $18,306 \ddagger$ \\
\hline Delaware & NA & NA & $2,909 *$ & North Dakota & 323 & 1,139 & 816 \\
\hline Florida & NA & NA & $24,339 \ddagger$ & Ohio & NA & NA & 4,808 \\
\hline Georgia & NA & NA & $19,777 \ddagger$ & Oklahoma & NA & NA & 3,898† \\
\hline Hawaii & $2,089 \ddagger$ & 5,422 & 3,333 & Oregon & NA & NA & $1,999 \ddagger$ \\
\hline Idaho & NA & NA & $1,137 *$ & Pennsylvania & NA & NA & 7,872 \\
\hline Illinois & NA & NA & $6,837 \ddagger$ & Rhode Island & NA & NA & 263 \\
\hline Indiana & NA & NA & $4,041 *$ & South Carolina & NA & NA & 9,455 \\
\hline Iowa & NA & NA & 3,517 & South Dakota & 530 & 1,758 & 1,228 \\
\hline Kansas & $1,241 *$ & 4,064 & 2,823 & Tennessee & 3,536 & 11,374 & 7,839 \\
\hline Kentucky & NA & NA & 4,435 & Texas & NA & NA & 30,445 \\
\hline Louisiana & 2,531‡ & 5,367 & 2,836 & Utah & 1,227 & 3,001 & 1,774 \\
\hline Maine & NA & NA & $1,000 \ddagger$ & Vermont & NA & NA & $378 *$ \\
\hline Maryland & NA & NA & NA & Virginia & NA & NA & $11,906 \dagger$ \\
\hline Massachusetts & NA & NA & 1,915 & Washington & NA & NA & $3,945 \ddagger$ \\
\hline Michigan & NA & NA & $7,567 *$ & West Virginia & 522 & 1,816 & 1,294 \\
\hline Minnesota & $2,500 \dagger$ & 11,757 & 9,257 & Wisconsin & NA & NA & $6,503 \dagger$ \\
\hline Mississippi & 1,793 & 4,298 & 2,505 & Wyoming & 176 & 510 & 334 \\
\hline Missouri & 2,046 & 6,643 & 4,597 & Washington, D.C. & NA & NA & $385 \ddagger$ \\
\hline Montana & NA & NA & $394+$ & & & & \\
\hline
\end{tabular}

Source: PNNL Cost-Effectiveness Database.

NA - not applicable. State already has adopted 2009 IECC or equivalent (Maryland has adopted 2012).

* State code slightly amends IECC code. Analysis used IECC.

†State code amends IECC. Custom state cost-effectiveness and custom analysis in this report.

$\ddagger$ State code amends IECC. No custom analysis available. Analysis used IECC. 
Table B.9. Statewide Value of Annual Natural Gas Savings by State by Building Energy Code Upgrade, 2000-2010 Average Level of Housing Starts

\begin{tabular}{|c|c|c|c|c|c|c|c|}
\hline \multicolumn{8}{|c|}{ Statewide Value of Annual Natural Gas Savings (Thousand 2011\$) } \\
\hline State & 2006-2009 & 2006-2012 & 2009-2012 & State & 2006-2009 & 2006-2012 & 2009-2012 \\
\hline Alabama & NA & NA & 1,484 & Nebraska & NA & NA & 1,064 \\
\hline Alaska & $215 \ddagger$ & 897 & 682 & Nevada & NA & NA & 4,805 \\
\hline Arizona & 1,252 & 6,432 & 5,180 & New Hampshire & NA & NA & $1,479 \ddagger$ \\
\hline Arkansas & 352 & 1,582 & 1,230 & New Jersey & NA & NA & $6,706 \ddagger$ \\
\hline California & NA & NA & $10,678 \ddagger$ & New Mexico & NA & NA & $1,335 \ddagger$ \\
\hline Colorado & 1,770 & 7,513 & 5,743 & New York & NA & NA & $12,144 \ddagger$ \\
\hline Connecticut & NA & NA & $1,808^{*}$ & North Carolina & NA & NA & $3,051 \ddagger$ \\
\hline Delaware & NA & NA & $488^{*}$ & North Dakota & 173 & 726 & 553 \\
\hline Florida & NA & NA & $2,325 \ddagger$ & Ohio & NA & NA & 7,454 \\
\hline Georgia & NA & NA & $3,771 \ddagger$ & Oklahoma & NA & NA & $1,440 \dagger$ \\
\hline Hawaii & $0 \ddagger$ & 0 & 0 & Oregon & NA & NA & $3,167 \ddagger$ \\
\hline Idaho & NA & NA & $2,409 *$ & Pennsylvania & NA & NA & 9,711 \\
\hline Illinois & NA & NA & $7,617 \ddagger$ & Rhode Island & NA & NA & 532 \\
\hline Indiana & NA & NA & $5,627 *$ & South Carolina & NA & NA & 1,415 \\
\hline Iowa & NA & NA & 2,173 & South Dakota & 251 & 1,070 & 818 \\
\hline Kansas & $574 *$ & 2,284 & 1,710 & Tennessee & 567 & 2,402 & 1,835 \\
\hline Kentucky & NA & NA & 1,177 & Texas & NA & NA & 8,108 \\
\hline Louisiana & $305 \ddagger$ & 1,427 & 1,123 & Utah & 906 & 3,870 & 2,964 \\
\hline Maine & NA & NA & $2,073 \ddagger$ & Vermont & NA & NA & $819 *$ \\
\hline Maryland & NA & NA & NA & Virginia & NA & NA & $2,014 \dagger$ \\
\hline Massachusetts & NA & NA & 4,375 & Washington & NA & NA & $6,953 \ddagger$ \\
\hline Michigan & NA & NA & $10,697 *$ & West Virginia & 70 & 290 & 219 \\
\hline Minnesota & $852 \dagger$ & 6,593 & 5,741 & Wisconsin & NA & NA & $8,386 \dagger$ \\
\hline Mississippi & 154 & 689 & 534 & Wyoming & 190 & 807 & 618 \\
\hline Missouri & 1,195 & 4,896 & 3,701 & Washington, D.C. & NA & NA & $58 \ddagger$ \\
\hline Montana & NA & NA & 691‡ & & & & \\
\hline
\end{tabular}

Source: PNNL Cost-Effectiveness Database.

NA - not applicable. State already has adopted 2009 IECC or equivalent (Maryland has adopted 2012).

* State code slightly amends IECC code. Analysis used IECC.

†State code amends IECC. Custom state cost-effectiveness and custom analysis in this report.

$¥$ State code amends IECC. No custom analysis available. Analysis used IECC. 
Table B.10. Statewide Value of Annual Fuel Oil Savings by State by Building Energy Code Upgrade, 2000-2010 Average Level of Housing Starts

\begin{tabular}{|c|c|c|c|c|c|c|c|}
\hline \multicolumn{8}{|c|}{ Statewide Value of Annual Fuel Oil Savings (Thousand 2011\$) } \\
\hline State & 2006-2009 & 2006-2012 & 2009-2012 & State & 2006-2009 & 2006-2012 & 2009-2012 \\
\hline Alabama & NA & NA & 0 & Nebraska & NA & NA & 8 \\
\hline Alaska & $0 \ddagger$ & 6 & 6 & Nevada & NA & NA & 30 \\
\hline Arizona & 0 & 0 & 0 & New Hampshire & NA & NA & $1,366 \ddagger$ \\
\hline Arkansas & 0 & 0 & 0 & New Jersey & NA & NA & $831 \ddagger$ \\
\hline California & NA & NA & $0 \ddagger$ & New Mexico & NA & NA & $9 \ddagger$ \\
\hline Colorado & 0 & 36 & 36 & New York & NA & NA & $1,552 \ddagger$ \\
\hline Connecticut & NA & NA & $1,824^{*}$ & North Carolina & NA & NA & $0 \neq$ \\
\hline Delaware & NA & NA & $6^{*}$ & North Dakota & 3 & 7 & 3 \\
\hline Florida & NA & NA & $155 \ddagger$ & Ohio & NA & NA & 112 \\
\hline Georgia & NA & NA & $0 \ddagger$ & Oklahoma & NA & NA & $0 \dagger$ \\
\hline Hawaii & $0 \ddagger$ & 0 & 0 & Oregon & NA & NA & $20 \ddagger$ \\
\hline Idaho & NA & NA & $12 *$ & Pennsylvania & NA & NA & 1,361 \\
\hline Illinois & NA & NA & $184 \ddagger$ & Rhode Island & NA & NA & 505 \\
\hline Indiana & NA & NA & $120 *$ & South Carolina & NA & NA & 0 \\
\hline Iowa & NA & NA & 25 & South Dakota & 5 & 14 & 9 \\
\hline Kansas & $0^{*}$ & 12 & 12 & Tennessee & 0 & 0 & 0 \\
\hline Kentucky & NA & NA & 0 & Texas & NA & NA & 0 \\
\hline Louisiana & $0 \ddagger$ & 0 & 0 & Utah & 19 & 38 & 19 \\
\hline Maine & NA & NA & $1,817 \ddagger$ & Vermont & NA & NA & $711^{*}$ \\
\hline Maryland & NA & NA & NA & Virginia & NA & NA & $36 \dagger$ \\
\hline Massachusetts & NA & NA & 4,012 & Washington & NA & NA & $39 \ddagger$ \\
\hline Michigan & NA & NA & $172 *$ & West Virginia & 0 & 4 & 4 \\
\hline Minnesota & $27 \dagger$ & 55 & 27 & Wisconsin & NA & NA & $143 \dagger$ \\
\hline Mississippi & 0 & 0 & 0 & Wyoming & 0 & 6 & 6 \\
\hline Missouri & 0 & 46 & 46 & Washington, D.C. & NA & NA & $0 \ddagger$ \\
\hline Montana & NA & NA & $7 \ddagger$ & & & & \\
\hline
\end{tabular}

Source: PNNL Cost-Effectiveness Database.

NA - not applicable. State already has adopted 2009 IECC or equivalent (Maryland has adopted 2012).

* State code slightly amends IECC code. Analysis used IECC.

†State code amends IECC. Custom state cost-effectiveness and custom analysis in this report.

$\ddagger$ State code amends IECC. No custom analysis available. Analysis used IECC. 


\section{B.4 Long-Term Consumer Spending of Energy Savings at the 2000- 2010 Average Level of Housing Starts}

Table B.11. Statewide Incremental Mortgage Payments to Meet the 2009 and 2012 IECC Building Energy Codes, Housing Starts Equal to Average Level 2000-2010

\begin{tabular}{|c|c|c|c|c|c|c|c|}
\hline \multicolumn{8}{|c|}{ Statewide Incremental Mortgage Payments (Thousand 2011\$) } \\
\hline State & 2006-2009 & 2006-2012 & 2009-2012 & State & 2006-2009 & 2006-2012 & 2009-2012 \\
\hline Alabama & NA & NA & 2,344 & Nebraska & NA & NA & 635 \\
\hline Alaska & $112 \ddagger$ & 554 & 442 & Nevada & NA & NA & 4,231 \\
\hline Arizona & 4,326 & 10,246 & 5,920 & New Hampshire & NA & NA & $642 \ddagger$ \\
\hline Arkansas & 644 & 1,828 & 1,183 & New Jersey & NA & NA & $3,048 \ddagger$ \\
\hline California & NA & NA & $18,821 \ddagger$ & New Mexico & NA & NA & $876 \ddagger$ \\
\hline Colorado & 1,770 & 5,093 & 3,323 & New York & NA & NA & $4,885 \ddagger$ \\
\hline Connecticut & NA & NA & $815 *$ & North Carolina & NA & NA & $7,516 \ddagger$ \\
\hline Delaware & NA & NA & $659 *$ & North Dakota & 117 & 503 & 383 \\
\hline Florida & NA & NA & $14,417 \ddagger$ & Ohio & NA & NA & 3,205 \\
\hline Georgia & NA & NA & 8,926‡ & Oklahoma & NA & NA & $1,850 \dagger$ \\
\hline Hawaii & $610 \neq$ & 1,292 & 682 & Oregon & NA & NA & $2,177 \ddagger$ \\
\hline Idaho & NA & NA & $1,236 *$ & Pennsylvania & NA & NA & 3,715 \\
\hline Illinois & NA & NA & $4,222 \ddagger$ & Rhode Island & NA & NA & 201 \\
\hline Indiana & NA & NA & $2,664 *$ & South Carolina & NA & NA & 3,934 \\
\hline Iowa & NA & NA & 1,181 & South Dakota & 209 & 753 & 544 \\
\hline Kansas & $351 *$ & 1,441 & 1,089 & Tennessee & 1,134 & 4,236 & 3,135 \\
\hline Kentucky & NA & NA & 1,613 & Texas & NA & NA & 14,687 \\
\hline Louisiana & $1,370 \ddagger$ & 3,312 & 1,941 & Utah & 925 & 2,643 & 1,718 \\
\hline Maine & NA & NA & $890 \ddagger$ & Vermont & NA & NA & $340 *$ \\
\hline Maryland & NA & NA & NA & Virginia & NA & NA & $4,209 \dagger$ \\
\hline Massachusetts & NA & NA & 1,602 & Washington & NA & NA & $4,102 \ddagger$ \\
\hline Michigan & NA & NA & $3,543 *$ & West Virginia & 171 & 601 & 430 \\
\hline Minnesota & $1,868 \dagger$ & 6,043 & 4,175 & Wisconsin & NA & NA & $4,022 \dagger$ \\
\hline Mississippi & 819 & 2,078 & 1,247 & Wyoming & 130 & 487 & 360 \\
\hline Missouri & 781 & 3,172 & 2,413 & Washington D.C. & NA & NA & $113 \ddagger$ \\
\hline Montana & NA & NA & $448 \ddagger$ & & & & \\
\hline
\end{tabular}

Source: PNNL Cost-Effectiveness Database.

NA - not applicable. State already has adopted 2009 IECC or equivalent (Maryland has adopted 2012).

* State code slightly amends IECC code. Analysis used IECC.

†State code amends IECC. Custom state cost-effectiveness and custom analysis in this report.

$¥$ State code amends IECC. No custom analysis available. Analysis used IECC. 
Table B.12. Statewide Incremental Property Tax Payments to Meet the 2009 and 2012 IECC Building Energy Codes, Housing Starts Equal to Average Level 2000-2010

\begin{tabular}{|c|c|c|c|c|c|c|c|}
\hline \multicolumn{8}{|c|}{ Statewide Incremental Insurance Payments (Thousand 2011\$) } \\
\hline State & 2006-2009 & 2006-2012 & 2009-2012 & State & 2006-2009 & 2006-2012 & 2009-2012 \\
\hline Alabama & NA & NA & 366 & Nebraska & NA & NA & 99 \\
\hline Alaska & $17 \ddagger$ & 86 & 69 & Nevada & NA & NA & 665 \\
\hline Arizona & 683 & 1,594 & 911 & New Hampshire & NA & NA & $101 \ddagger$ \\
\hline Arkansas & 105 & 293 & 187 & New Jersey & NA & NA & $471 \ddagger$ \\
\hline California & NA & NA & $2,937 \ddagger$ & New Mexico & NA & NA & $136 \ddagger$ \\
\hline Colorado & 289 & 795 & 542 & New York & NA & NA & $776 \neq$ \\
\hline Connecticut & NA & NA & $126^{*}$ & North Carolina & NA & NA & $1,191 \ddagger$ \\
\hline Delaware & NA & NA & $105^{*}$ & North Dakota & 20 & 80 & 60 \\
\hline Florida & NA & NA & $2,325 \ddagger$ & Ohio & NA & NA & 522 \\
\hline Georgia & NA & NA & $1,385 \ddagger$ & Oklahoma & NA & NA & $291 \dagger$ \\
\hline Hawaii & $97 \ddagger$ & 205 & 109 & Oregon & NA & NA & $336 \ddagger$ \\
\hline Idaho & NA & NA & $198^{*}$ & Pennsylvania & NA & NA & 589 \\
\hline Illinois & NA & NA & $688 \ddagger$ & Rhode Island & NA & NA & 31 \\
\hline Indiana & NA & NA & $419 *$ & South Carolina & NA & NA & 621 \\
\hline Iowa & NA & NA & 188 & South Dakota & 33 & 121 & 84 \\
\hline Kansas & $59 *$ & 223 & 176 & Tennessee & 167 & 667 & 500 \\
\hline Kentucky & NA & NA & 258 & Texas & NA & NA & 2,295 \\
\hline Louisiana & $209 \ddagger$ & 514 & 305 & Utah & 151 & 415 & 264 \\
\hline Maine & NA & NA & $140 \ddagger$ & Vermont & NA & NA & $53^{*}$ \\
\hline Maryland & NA & NA & NA & Virginia & NA & NA & $647 \dagger$ \\
\hline Massachusetts & NA & NA & 248 & Washington & NA & NA & $664 \ddagger$ \\
\hline Michigan & NA & NA & $550 *$ & West Virginia & 26 & 97 & 66 \\
\hline Minnesota & $302 \dagger$ & 961 & 659 & Wisconsin & NA & NA & $628 \dagger$ \\
\hline Mississippi & 131 & 332 & 202 & Wyoming & 20 & 76 & 57 \\
\hline Missouri & 115 & 506 & 391 & Washington D.C. & NA & NA & $17 \ddagger$ \\
\hline Montana & NA & NA & 71市 & & & & \\
\hline
\end{tabular}

Source: PNNL Cost-Effectiveness Database.

NA - not applicable. State already has adopted 2009 IECC or equivalent (Maryland has adopted 2012).

* State code slightly amends IECC code. Analysis used IECC.

†State code amends IECC. Custom state cost-effectiveness and custom analysis in this report.

$\ddagger$ State code amends IECC. No custom analysis available. Analysis used IECC. 
Table B.13. Statewide Incremental Insurance Payments to Meet the 2009 and 2012 IECC Building Energy Codes, Housing Starts Equal to Average Level 2000-2010

\begin{tabular}{|c|c|c|c|c|c|c|c|}
\hline \multicolumn{8}{|c|}{ Statewide Incremental Insurance Payments (Thousand 2011\$) } \\
\hline State & 2006-2009 & 2006-2012 & 2009-2012 & State & 2006-2009 & 2006-2012 & 2009-2012 \\
\hline Alabama & NA & NA & 194 & Nebraska & NA & NA & 49 \\
\hline Alaska & $8 \ddagger$ & 44 & 36 & Nevada & NA & NA & 332 \\
\hline Arizona & 342 & 854 & 455 & New Hampshire & NA & NA & $53 \ddagger$ \\
\hline Arkansas & 47 & 152 & 94 & New Jersey & NA & NA & $249 \ddagger$ \\
\hline California & NA & NA & $1,468 \ddagger$ & New Mexico & NA & NA & $68 \ddagger$ \\
\hline Colorado & 144 & 397 & 253 & New York & NA & NA & $411 \ddagger$ \\
\hline Connecticut & NA & NA & $67 *$ & North Carolina & NA & NA & $595 \ddagger$ \\
\hline Delaware & NA & NA & $55^{*}$ & North Dakota & 10 & 40 & 30 \\
\hline Florida & NA & NA & $1,085 \ddagger$ & Ohio & NA & NA & 261 \\
\hline Georgia & NA & NA & $693 \ddagger$ & Oklahoma & NA & NA & $145 \dagger$ \\
\hline Hawaii & $48 \ddagger$ & 103 & 54 & Oregon & NA & NA & $178 \ddagger$ \\
\hline Idaho & NA & NA & $99 *$ & Pennsylvania & NA & NA & 294 \\
\hline Illinois & NA & NA & $321 \ddagger$ & Rhode Island & NA & NA & 17 \\
\hline Indiana & NA & NA & $210 *$ & South Carolina & NA & NA & 311 \\
\hline Iowa & NA & NA & 100 & South Dakota & 19 & 60 & 42 \\
\hline Kansas & $23 *$ & 117 & 94 & Tennessee & 100 & 334 & 267 \\
\hline Kentucky & NA & NA & 129 & Texas & NA & NA & 1,224 \\
\hline Louisiana & $114 \ddagger$ & 266 & 152 & Utah & 76 & 208 & 132 \\
\hline Maine & NA & NA & $73 \ddagger$ & Vermont & NA & NA & $27^{*}$ \\
\hline Maryland & NA & NA & NA & Virginia & NA & NA & $324 \dagger$ \\
\hline Massachusetts & NA & NA & 132 & Washington & NA & NA & $313 \ddagger$ \\
\hline Michigan & NA & NA & $275^{*}$ & West Virginia & 13 & 48 & 35 \\
\hline Minnesota & $165 \dagger$ & 494 & 330 & Wisconsin & NA & NA & $314 \dagger$ \\
\hline Mississippi & 71 & 166 & 95 & Wyoming & 11 & 40 & 28 \\
\hline Missouri & 69 & 253 & 184 & Washington D.C. & NA & NA & $9 \ddagger$ \\
\hline Montana & NA & NA & $37 \ddagger$ & & & & \\
\hline
\end{tabular}

Source: PNNL Cost-Effectiveness Database.

NA - not applicable. State already has adopted 2009 IECC or equivalent (Maryland has adopted 2012).

* State code slightly amends IECC code. Analysis used IECC.

†State code amends IECC. Custom state cost-effectiveness and custom analysis in this report.

$¥$ State code amends IECC. No custom analysis available. Analysis used IECC. 
Table B.14. Other Statewide Consumer Spending Out of Energy Savings from Meeting the 2009 and 2012 IECC Building Energy Codes, Housing Starts Equal to Average Level 2000-2010

\begin{tabular}{|c|c|c|c|c|c|c|c|}
\hline \multicolumn{8}{|c|}{ Other Statewide Consumer Spending Out of Energy Savings (Thousand 2011\$) } \\
\hline State & 2006-2009 & 2006-2012 & 2009-2012 & State & 2006-2009 & 2006-2012 & 2009-2012 \\
\hline Alabama & NA & NA & 3,957 & Nebraska & NA & NA & 2,053 \\
\hline Alaska & $600 \ddagger$ & 2,057 & 1,455 & Nevada & NA & NA & 6,468 \\
\hline Arizona & 8,766 & 17,248 & 8,539 & New Hampshire & NA & NA & $2,542 \ddagger$ \\
\hline Arkansas & 1,090 & 3,632 & 2,566 & New Jersey & NA & NA & $11,057 \ddagger$ \\
\hline California & NA & NA & $3,871 \ddagger$ & New Mexico & NA & NA & $1,573 \ddagger$ \\
\hline Colorado & 2,492 & 9,030 & 6,501 & New York & NA & NA & 21,320市 \\
\hline Connecticut & NA & NA & $4,010^{*}$ & North Carolina & NA & NA & $12,874 \ddagger$ \\
\hline Delaware & NA & NA & $2,753^{*}$ & North Dakota & 373 & 1,349 & 979 \\
\hline Florida & NA & NA & $11,782 \ddagger$ & Ohio & NA & NA & 9,020 \\
\hline Georgia & NA & NA & $14,698 \ddagger$ & Oklahoma & NA & NA & $3,541 \dagger$ \\
\hline Hawaii & $1,497 \ddagger$ & 4,148 & 2,651 & Oregon & NA & NA & $2,078 \ddagger$ \\
\hline Idaho & NA & NA & $2,298^{*}$ & Pennsylvania & NA & NA & 15,155 \\
\hline Illinois & NA & NA & $10,095 \ddagger$ & Rhode Island & NA & NA & 1,099 \\
\hline Indiana & NA & NA & $6,974^{*}$ & South Carolina & NA & NA & 6,143 \\
\hline Iowa & NA & NA & 4,547 & South Dakota & 563 & 2,041 & 1,483 \\
\hline Kansas & $1,464 *$ & 4,931 & 3,443 & Tennessee & 2,935 & 9,406 & 6,438 \\
\hline Kentucky & NA & NA & 4,016 & Texas & NA & NA & 24,172 \\
\hline Louisiana & $1,465 \ddagger$ & 3,502 & 2,036 & Utah & 1,170 & 4,190 & 3,020 \\
\hline Maine & NA & NA & $4,006 \ddagger$ & Vermont & NA & NA & $1,571^{*}$ \\
\hline Maryland & NA & NA & NA & Virginia & NA & NA & $9,784 \dagger$ \\
\hline Massachusetts & NA & NA & 8,652 & Washington & NA & NA & $6,641 \ddagger$ \\
\hline Michigan & NA & NA & $14,721^{*}$ & West Virginia & 421 & 1,505 & 1,088 \\
\hline Minnesota & $1,483 \dagger$ & 12,362 & 10,878 & Wisconsin & NA & NA & $10,924 \dagger$ \\
\hline Mississippi & 1,116 & 2,909 & 1,805 & Wyoming & 235 & 810 & 572 \\
\hline Missouri & 2,505 & 8,481 & 5,953 & Washington D.C. & NA & NA & $330 \ddagger$ \\
\hline Montana & NA & NA & $630 \ddagger$ & & & & \\
\hline
\end{tabular}

Source: PNNL Cost-Effectiveness Database.

NA - not applicable. State already has adopted 2009 IECC or equivalent (Maryland has adopted 2012).

* State code slightly amends IECC code. Analysis used IECC.

$\dagger$ State code amends IECC. Custom state cost-effectiveness and custom analysis in this report.

$\ddagger$ State code amends IECC. No custom analysis available. Analysis used IECC. 


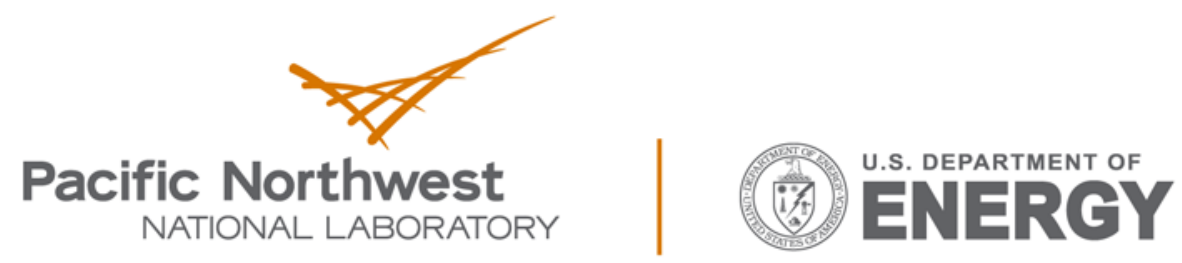

Proudly Operated by Battelle Since 1965

902 Battelle Boulevard

P.O. Box 999

Richland, WA 99352

1-888-375-PNNL (7665)

www.pnnl.gov 